\title{
Biomass Adsorbent for Removal of Toxic Metal Ions From Electroplating Industry Wastewater
}

\author{
Ronaldo Ferreira do. Nascimento ${ }^{1}$, Francisco Wagner de Sousa ${ }^{1}$, \\ Vicente Oliveira Sousa Neto ${ }^{2}$, Pierre Basílio Almeida Fechine ${ }^{1}$, \\ Raimundo Nonato Pereira Teixeira ${ }^{3}$, Paulo de Tarso C. Freire ${ }^{1}$ \\ and Marcos Antônio Araujo-Silva ${ }^{1}$ \\ 1 Universidade Federal do Ceara (UFC), \\ 2 Universidade Estadual do Ceara (UECE-CECITEC), \\ ${ }^{3}$ Universidade Regional do Cariri (URCA), \\ ${ }^{4}$ Instituto Federal de Educação, Ciência e Tecnologia (IFCE-Crateús) \\ Brazil
}

\section{Introduction}

The contamination of water bodies by heavy metals has been the subject of many studies worldwide. Several alternatives have been proposed in order to minimize the harmful effects that the disposal of these metals can cause to the environment.

A major challenge for the electroplating industry is finding solutions that equate to positive environmental and economic aspects regarding the treatment of their effluent. The adsorption process has been widely studied in order to solve the problem of many industries regarding the disposal of their effluent. Systems such as ion exchange resins, electrochemical process, chemical precipitation and activated carbon have been widely used in the processes of waste water purification. Such processes could have reduced its costs from the use of alternative materials for low cost. This has led many industries worldwide to invest in research aimed at obtaining cheap and plentiful materials that may have the same or greater capacity to remove pollutants from water bodies.

The biosorption has been presented as a promising alternative to solve the problem of contamination by heavy metals with low environmental and economic impacts.

In this chapter we introduce biosorption e process of heavy metals and discuss the implications of the technologies used in the electroplating industry to remove its contaminants.

\subsection{Biosorbents}

Materials of natural origin are generally used in biosorption studies (such as seaweed, biological depuration plant sludge, agricultural and industrial wastes) are inexhaustible, low-cost and non-hazardous materials, which are specifically selective for different contaminants and easily disposed by incineration.

The biosorbent terms refers to material derived from microbial biomass, seaweed or plants that exhibit adsorptive properties. Biosorption is the accumulation of metals by biological 
materials without active uptake. This process may include ion exchange, coordination, complexation, chelation, adsorption and microprecipitation (Duncan et al., 1994) This biomass must be subjected to pre-treatment to obtain a better operating performance in pollutant removal using adsorption method (Naja et al., 2010).

An interesting feature is that the biosorbents are widely found in nature and they have low cost. In some cases they are agriculture waste such as corn cob (Shen \& Duvnjak, 2005), coconut shell (Sousa, 2007), orange pulp (Almeida, 2005), peat (Gupta et al 2009) and sawdust (Yasemin \& Zaki, 2007)

\section{2 lons metal biosorption}

The process is based on the interaction of ions at the interface biomass / aqueous medium. The sorbent can be either a particulate material as a compact material. The separation can be performed in packed columns, fluidized beds or in the form of discs to be used in the filtration process. This configuration allows for regeneration and reuse of the adsorbent and its proper disposal (Vargas et al, 1995). The discovery and development of the biosorption process has supported the basis for an new technology in this field. Several authors have been devoted to the study and applicability of this new kind of technology (White, 1995; Volesky, 1990).

Agricultural waste is one of the rich sources of low-cost adsorbents besides industrial byproduct and natural material. Due to its abundant availability agricultural waste such as peanut husk, rice husk, coconut shell, wheat bran and sawdust offer little economic value and, moreover, create serious disposal problems (Igwe \& Abia,2007).

Biosorption is the capability of active sites on the surface of biomaterials to bind and concentrate heavy metals from even the most dilute aqueous solutions. Biosorption can be used for the treatment of wastewater with low heavy metal concentration as an inexpensive, simple and effective alternative to conventional methods. The process of metal ion binding is comprised of many physico-chemical processes like ion exchange, complexation, microprecipitation, and electrostatic interactions. Biosorbents for the removal of metals mainly come under the following categories: bacteria, fungi, algae, industrial wastes, agricultural wastes and other polysaccharide materials. In general, all types of biomaterials have shown good biosorption capacities towards all types of metal ions (Febrianto et al., 2009)

The biosorption results from electrostatic interactions and/or of the formation of complexes between metal ions and functional groups present on the surface of biosorbent. So many studies have been conducted to assess the potential for removing heavy metals from various biological materials (Hayashi , 2001). We can cite the seaweeds and their derivatives (Luo et al, 2006), chitosan (Ngah et al, 2011), lignin (Guo et al, 2008), wide variety of bacteria and fungi (Watanabe et al, 2003), agricultural residues (Sousa, 2007), among others. According to Volesky, (1990) biosorbent must have certain physical characteristics (surface area, porosity, grain size etc.) to get good ability to adsorption and to be used in an adsorption process.

\subsection{Adsorbent used for removing pollutants}

Adsorption process is essentially a surface phenomenon. Adsorbent having a good adsorptive capacity implies that it should present a large specific surface area. The adsorptive properties depend on the distribution of size pore and the nature of the solid surface. The adsorbents 
most commonly used on an industrial scale are the activated carbon, silica gel, activated alumina and molecular sieves (Lopez \& Gutarra, 2000) (Yasemin \& Zaki, 2007). There is no doubt that the charcoal has become the most widely used solid, worldwide, as an adsorbent to remove pollutants in wastewater. According to its own characteristics, such as high porosity, chemical structure and high surface area, the activated carbon has an excellent ability to remove substances on its surface (Babel \& Kurniawan, 2003). Added to this, the chemical structure of this material allows surface modifications by chemical or physical treatments, allowing an increase in adsorption capacity of this material.

On the other hand, it is also widespread agreement that even with all these features, the charcoal has some serious drawbacks to adsorptive processes. Some of them should be, for example, the fact that this material is not selective, and its market value is relatively high. Also, the reactivation of this material is not an easy process; cleaning the surface for subsequent applications is a one very expensive process. Moreover, the methods of recovery of coal, both the heat treatment as the use of chemicals, cannot regenerate the material with the same initial characteristics, leading to losses in their adsorption capacity. For these reasons, special attention has been focused on several other adsorbent materials. In particular, some natural materials, such as polysaccharides, clays, biomass, etc., that can remove pollutants from contaminated water at low cost of procurement has been widely researched around the world (Kumar, 2000; Crini, 2005, Crini, 2006). In fact, the cost of obtaining and regenerative capacity of such solid materials are important parameters when compared adsorbents materials.

\begin{tabular}{|c|c|c|c|c|c|}
\hline № & $\mathrm{pH}$ & Adsorbent & Metal & $\begin{array}{l}\text { Adsorption } \\
\text { capacity } \\
\text { qm }\left(\mathrm{mg}^{-1}\right)\end{array}$ & Reference \\
\hline 1 & - & Pomelo peel & $\mathrm{Cd}(\mathrm{II})$ & 21.83 & (Saikaew et al, 2009) \\
\hline 2 & 6 & $\begin{array}{l}\text { Acid-treated coconut } \\
\text { shell carbon }\end{array}$ & $\mathrm{Zn}(\mathrm{II})$ & 60.41 & (Amuda et al, 2007) \\
\hline 3 & 5 & Caladium bicolor & $\mathrm{Cd}(\mathrm{II})$ & 42.19 & (Jnr et al, 2005) \\
\hline 4 & - & $\begin{array}{l}\mathrm{H}_{3} \mathrm{PO}_{4} \text { reated } \\
\text { rice bran }\end{array}$ & $\mathrm{Ni}(\mathrm{II})$ & 102 & (Zafar et al,2007) \\
\hline 5 & $6.6-6.8$ & Rice husk modified & $\mathrm{Cd}(\mathrm{II})$ & 20.24 & $\begin{array}{c}\text { (Kumar and } \\
\text { Bandyopadhyay, 2006) }\end{array}$ \\
\hline 6 & 5.3 & Gelidium & $\begin{array}{l}\mathrm{Zn}(\mathrm{II}) \\
\mathrm{Cr}(\mathrm{III})\end{array}$ & $\begin{array}{l}13 \\
18\end{array}$ & (Vilar et al, 2007) \\
\hline 7 & 5.3 & Algal waste & $\begin{array}{l}\mathrm{Zn}(\mathrm{II}) \\
\mathrm{Cr}(\mathrm{III})\end{array}$ & $\begin{array}{c}7.1 \\
11.8\end{array}$ & (Vilar et al, 2007) \\
\hline $\begin{array}{l}8 \\
9\end{array}$ & $\begin{array}{l}5.0 \\
5.5\end{array}$ & $\begin{array}{c}\text { Valonia tannin resin } \\
\text { Lignin }\end{array}$ & $\begin{array}{l}\mathrm{Cu}(\mathrm{II}) \\
\mathrm{Cd}(\mathrm{II})\end{array}$ & $\begin{array}{l}44.24 \\
25.4\end{array}$ & $\begin{array}{l}\text { (Sengil et al, 2009) } \\
\text { (Guo, 2008) }\end{array}$ \\
\hline 10 & 5.3 & Modified wood & $\begin{array}{l}\mathrm{Cu}(\mathrm{II}) \\
\mathrm{Pb}(\mathrm{II})\end{array}$ & $\begin{array}{l}23.7 \\
82.6\end{array}$ & (Low et al,2004) \\
\hline
\end{tabular}

Table 1. Maximum adsorption capacity of some adsorbent system given in literature

\subsection{Modification of adsorbent}

In general, raw lignocellulosic biosorbents were modified by various methods to increase their adsorption capacities because metal ion binding by lignocellulosic biosorbents is believed to take place through chemical functional groups such as carboxyl, amino, or phenolics. More recently, great effort has been contributed to develop new adsorbents and 
improve existing adsorbents. Many investigators have studied the feasibility of using lowcost agro-based waste materials (Hashem, 2006; Hashem et al.,2006; Hashem et al. ,2006; Hashem et al., 2006; Hashem et al., 2006, Abdel-Halim et al., 2006; Hashem et al., 2006)

Agricultural by-products usually are composed of lignin and cellulose as major constituents and may also include other polar functional groups of lignin, which includes alcohols, aldehydes, ketones, carboxylic, phenolic and ether groups. These groups have the ability to some extent to bind heavy metals by donation of an electron pair from these groups to form complexes with the metal ions in solution (Pagnanelli, 2003).

In recent decades there has been a greater interest and concern about environmental issues. This has motivated the development of materials for low cost, wide availability and good adsorption capacity. At this particular point modification of adsorbent has been used in some cases with great success, with the purpose of increasing the adsorption capacity of these materials. Cellulose, hemicellulose and lignin are compounds that have structures with a large amount of hydroxyl groups. The availability of these groups are associated with good capacity to adsorb heavy metals such as $\mathrm{Cu}$ (II), Zn (II), Cd (II), Pb (II) among others. An interesting aspect is that these materials can be easily modified by introducing new functional groups.The modification reactions often employ a bioadsorbente polymerization reactions (Anirudhan \& Noeline, 2005), functionalization with carboxylic groups, amines, amides (Shiba \& Anirudhan, 2005) among others.

\subsection{Electroplating wastewater}

The industry of metal finishing and electroplating units are one of the major sources of pollutants which contribute greatly to the pollution load of the receiving water bodies and therefore increase the environmental risks

The industry of metal finishing and electroplating are one of the majorsource of heavy metals ( $\mathrm{Zn}, \mathrm{Cu}, \mathrm{Cr}, . .$.$) and cyanide (Monser \& Adhoum, 2002, 2002, Low \& Lee,1991.). in$ the world. With the development of electroplating, the quantity of the electroplating wastewater have increased so fast in the last years. The heavy metals must be removed from wastewaters before discharge, as they are considered persistent, bioaccumulative and toxic (Sankararamakrishnan et al., 2007; Gupta, 2008), causing a serious threat to public health.

Heavy metal pollution around plating factories has been associated with the expansion of the plating industry in developing countries (Morgan \& Lee, 1997 and Brower et al., 1997). Wastewater from the plating factories is divided into two types, one from plating manufacturing process and from rinsing process. In developed countries, removal of heavy metals in wastewater is normally achieved by advanced technologies such as ion exchange resins, vacuum evaporation, crystallization, solvent extraction and membrane technologies (Regel-Rosocka, 2010, Agrawal \& Sahu, 2009, Nagarale, 2006, Ulbricht,2006). However, in developing countries, these treatments cannot be applied because of technical levels and insufficient funds. Therefore, it is desired that simple and economic removal methods to be utilized in developing countries could be established. Although chemical precipitation and coagulation-flocculation have been widely used to treat electroplating wastewater, their drawbacks like excessive chemicals consumption, sludge production, and impossibility of directly reusing heavy metals are obvious. On the other hand, adsorption methods such as ion exchange and membrane separation are simple methods for the removal of heavy metals. However, there is a limit in the generality in developing countries because chelating 
and ion-exchange resins are expensive. Certainly, the cost plays an important and crucial role for determining which one is to be applied. Therefore, it is worthwhile to develop economic adsorbents of heavy metals which can be generally utilized in developing countries. Consequently, in the last decades alternative adsorbents for the treatment of heavy metal contamination have been investigated.

Cyanide is capable of forming a complex with almost any metal and resulting metal complexes. They are classified according to the strength of the metal-cyanide bond through the $\mathrm{pH}$ at which dissociation happens. Depending on the type of metal, some simple cyanides can dissolve in water forming metal ions and cyanide ions (equation 1):

$$
M_{y}(C N)_{x} \leftrightarrows M_{y}^{-}+x(C N)^{-}
$$

The solubility is influenced by $\mathrm{pH}$ and temperature (Botz et al., 1995) and the presence of other ligants as ammonia, for example (Franson, 1992).

Cyanide complexes can generally be described by the formulae $\operatorname{AyM}(\mathrm{CNx})$, where $\mathrm{A}$ is an alkali or alkali-earth, $\mathrm{y}$ is the number of ions of A present, $\mathrm{M}$ is normally a transition metal, and $x$ is the number of cyano-groups (Klenk et al., 1996).

Solution of metal ions, which already contain metal cyanide complexes, can replace the metal in the complex. The replacement depends on the respective formation constants. The metal ion in solution may also form a multimetal cyanide complex which may then precipitate as the complex, usually as an insoluble hydroxide or carbonate (Botz et al., 1995).

In the aqueous phase the equilibrium speciation of $\mathrm{Cu}(\mathrm{I})$ in cyanide solution can be represented by reactions (1)-(6) where $K_{1}-K_{4}$ are the equilibrium constants (here they are selected as $3.16 \times 10^{19}, 3.39 \times 10^{4}, 4.17 \times 10^{4}$ and 50.1, respectively (Lu et al., 2002).

$$
\begin{gathered}
\mathrm{Cu}^{+}+\mathrm{CN}^{-} \leftrightarrows \mathrm{CuCN} \mathrm{K}_{1}=\frac{[\mathrm{CuCN}]}{\left[\mathrm{Cu}^{+}\right]\left[\mathrm{CN}^{-}\right]}=3.16 \times 10^{19} \\
\mathrm{CuCN}+\mathrm{CN}^{-} \leftrightarrows \mathrm{CuCN}_{2}^{-} \mathrm{K}_{2}=\frac{\left[\mathrm{CuCN}_{2}^{-}\right]}{\left[{\mathrm{CuCN}]\left[\mathrm{CN}^{-}\right]}_{10}\right.}=3.39 \times 10^{4} \\
\mathrm{CuCN}_{2}^{-}+\mathrm{CN}^{-} \leftrightarrows \mathrm{CuCN}_{3}^{2-} \mathrm{K}_{3}=\frac{\left[\mathrm{CuCN}_{3}^{-}\right]}{\left[\mathrm{CuCN}_{2}^{-}\right]\left[\mathrm{CN}^{-}\right]}=4.17 \times 10^{4} \\
\mathrm{CuCN}_{3}^{2-}+\mathrm{CN}^{-} \leftrightarrows \mathrm{CuCN}_{4}^{3-} \mathrm{K}_{4}=\frac{\left[\mathrm{CuCN}_{4}^{3-}\right]}{\left[\mathrm{CuCN}_{3}^{2-}\right]\left[\mathrm{CN}^{-}\right]}=50.1 \\
\mathrm{CuCN}^{\leftrightarrows} \mathrm{Cu}^{+}+\mathrm{CN}^{-} \mathrm{K}_{\mathrm{sp}(5)}=\left[\mathrm{Cu}^{+}\right]\left[\mathrm{CN}^{-}\right]=10^{-20} \\
\mathrm{Cu}_{2} \mathrm{O}+\mathrm{H}_{2} \mathrm{O} \rightarrow 2 \mathrm{Cu}^{+}+2 \mathrm{OH}^{-} \mathrm{K}_{\mathrm{sp}(6)}=\left[\mathrm{Cu}^{+}\right]^{2}\left[\mathrm{OH}^{-}\right]^{2}=10^{-29.5}
\end{gathered}
$$

In the aqueous phase the equilibrium speciation of $\mathrm{Zn}(\mathrm{II})$ in cyanide solution can be represented by reactions (7)-(10) with the stability constant.

$$
\begin{gathered}
\mathrm{Zn}^{+2}+\mathrm{CN}^{-} \leftrightarrows\left[\mathrm{Zn}(C N)^{+}\right] \beta_{1}=\frac{[\mathrm{CuCN}]}{\left[\mathrm{Cu}^{+}\right]\left[\mathrm{CN}^{-}\right]}=10^{5.34} \\
\mathrm{Zn}^{+2}+2 \mathrm{CN}^{-} \leftrightarrows\left[\mathrm{Zn}(C N)_{2}\right] \beta_{2}=\frac{\left[\mathrm{Zn}(C N)_{2}\right]}{\left[\mathrm{Zn}^{+}\right]\left[\mathrm{CN}^{-}\right]^{2}}=10^{11.97}
\end{gathered}
$$




$$
\begin{aligned}
& \mathrm{Zn}^{+2}+3 \mathrm{CN}^{-} \leftrightarrows\left[\mathrm{Zn}(\mathrm{CN})_{3}^{-}\right] \beta_{3}=\frac{\left[\mathrm{ZnCN}_{3}^{-}\right]}{\left[\mathrm{Zn}^{+}\right]\left[\mathrm{CN}^{-}\right]^{3}}=10^{16.05} \\
& \mathrm{Zn}^{+2}+4 \mathrm{CN}^{-} \leftrightarrows\left[\mathrm{Zn}(\mathrm{CN})_{4}^{2-}\right] \beta_{3}=\frac{\left[\mathrm{Zn}(\mathrm{CN})_{4}^{2-}\right]}{\left[\mathrm{Zn}^{+}\right]\left[\mathrm{CN}^{-}\right]^{4}}=10^{19.62}
\end{aligned}
$$

The diagram of the Fig. 1 shows the speciation for the copper-cyanide-water system through the $\mathrm{pH}$ at which dissociation happens.

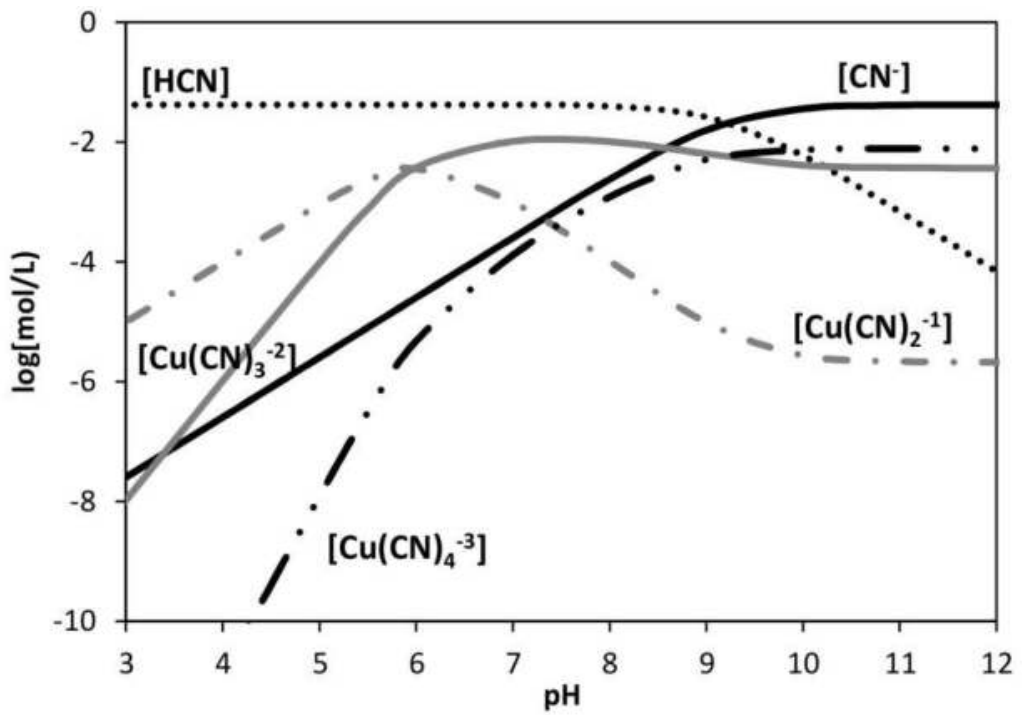

Fig. 1. Speciation diagram for the copper-cyanide-water system to $25^{\circ} \mathrm{C} ;[\mathrm{Cu}]=1.15 \times 10^{-2}$; $\left[\mathrm{CN}^{-}\right]=4.2 \times 10^{-2}\left(\mathrm{~K}_{1}=3.16 \times 10^{19} ; \mathrm{K}_{2}=3.39 \times 10^{4} ; \mathrm{K}_{3}=4.17 \times 10^{4} ; \mathrm{K}_{4}=50,1\right)$

\subsection{Metal cyanide complex on electroplating waterwaste}

Cyanide, a poisonous substance dangerous to humans, animals, plants and aquatic organisms, can be found in the effluent of several industries such as paint and ink formulation, petroleum refining, explosives, case hardening, automobile industry, chemicals industry, pesticides industries, synthetic fiber production, electroplating, thermoelectric power stations, mining, electronics, and coke (Akcil, 2003; Clesceri et al., 1998; Dash et al., 2008; Monteagudo, 2004; Abou-Elela, 2008; Saarela et al., 2005; Dutra et al., 2008; Park et al., 2008; Lanza \& Bertazzoli, 2002; Han et al., 2005; Mudder \& Botz, 2004; Yazıc1, 2007; Zvinowanda et al., 2008; Fernando et al., 2008, Monser \& Adhoum, 2002). Its effects on the human and the environment have been well reviewed by Mudder and Botz (2004). Due to its toxic nature, cyanide must be recovered, removed or destroyed.

The use of metals cyanide baths in the electroplating industry generates a strong concern related to environmental impacts due to high cadmium and cyanide toxicity (Smith and Mudder, 1991; Gijzen,2000; Waalkes, 2000). To minimize these environmental impacts wastewater treatment process are employed. The treatment intends to eliminate these toxic substances before their discharge in the environment (Butter et al., 1998). Several different cyanide removal technology are shown on table 2 


\begin{tabular}{|c|c|c|c|c|}
\hline Method & Description & Advantage & Disadvantage & Reference \\
\hline $\begin{array}{c}\text { Alkaline } \\
\text { chlorination }\end{array}$ & $\begin{array}{l}\text { Cyanide is } \\
\text { oxidized to } \\
\text { cyanate using } \\
\text { chlorine or } \\
\text { hypochlorite }\end{array}$ & Low cost when & $\begin{array}{l}\text { These methods do not } \\
\text { destroy the pollutants } \\
\text { completely. Complete } \\
\text { destruction of cyanate } \\
\text { is difficult; It is less } \\
\text { effective for iron } \\
\text { cyanides; cannot } \\
\text { recover cyanide; } \\
\text { remaining chloramines } \\
\text { and free chlorine lead } \\
\text { to secondary } \\
\text { contamination }\end{array}$ & $\begin{array}{l}\text { (Freeman,1989; } \\
\text { Han et al, 2005) }\end{array}$ \\
\hline $\begin{array}{l}\text { Hydrogen } \\
\text { peroxide } \\
\text { oxidation }\end{array}$ & $\begin{array}{c}\text { Cyanide is } \\
\text { oxidized to } \\
\text { cyanate using } \\
\text { hydrogen peroxide } \\
\text { in the presence of } \\
\text { copper ion }\end{array}$ & $\begin{array}{l}\text { High Efficiency; } \\
\text { Reactions involved in the } \\
\text { process are very fast }\end{array}$ & $\begin{array}{l}\text { Hydrogen peroxide is } \\
\text { hazardous and } \\
\text { expensive. Requires } \\
\text { specialized equipment } \\
\text { increasing the total } \\
\text { capital cost. The } \\
\text { treatment process } \\
\text { generates ammonia, } \\
\text { which is toxic to fish. }\end{array}$ & (Han et al, 2005) \\
\hline $\begin{array}{l}\text { Activated } \\
\text { carbon } \\
\text { adsorption }\end{array}$ & $\begin{array}{l}\text { Cyanide is } \\
\text { removed by } \\
\text { activated carbon } \\
\text { adsorption }\end{array}$ & $\begin{array}{c}\text { Activated carbon } \\
\text { performs both as an } \\
\text { adsorbent and as a } \\
\text { catalyst for the oxidation } \\
\text { of cyanide. The } \\
\text { adsorptive properties of } \\
\text { activated carbons result } \\
\text { from their high surface } \\
\text { area and high degree of } \\
\text { surface reactivity. }\end{array}$ & $\begin{array}{c}\text { Regeneration of } \\
\text { activated carbon is } \\
\text { difficult }\end{array}$ & $\begin{array}{l}\text { (Behnamfard \& } \\
\text { Salarirad,2009; } \\
\text { Han et al, 2005) }\end{array}$ \\
\hline $\begin{array}{c}\text { Photochemical } \\
\text { destruction }\end{array}$ & $\begin{array}{c}\text { Cyanide is } \\
\text { destroyed using } \\
\text { ultraviolet (UV) } \\
\text { irradiation }\end{array}$ & $\begin{array}{l}\text { It ensures destruction of } \\
\text { both free and some } \\
\text { cyanide complexes, with } \\
\text { weak-acid dissociable } \\
\text { metals such as copper, } \\
\text { without creating toxic } \\
\text { residue }\end{array}$ & $\begin{array}{c}\text { Usually inadequate by } \\
\text { itself and requires } \\
\text { chemical treatment, } \\
\text { The wastewater must } \\
\text { have a low } \\
\text { concentration of } \\
\text { organic matter }\end{array}$ & $\begin{array}{l}\text { (Barakat et al, } \\
\text { 2004; Han et al, } \\
\text { 2005) }\end{array}$ \\
\hline Ion exchange & $\begin{array}{l}\text { Cyanide is } \\
\text { removed by anion } \\
\text { exchange resin }\end{array}$ & $\begin{array}{l}\text { High selectivity of resins } \\
\text { to metal cyanide } \\
\text { complexes; Absence of } \\
\text { hydrocyanic acid vapor } \\
\text { which is hazardous to } \\
\text { health. }\end{array}$ & $\begin{array}{l}\text { Regeneration of resin } \\
\text { is difficult since there } \\
\text { are cyanide complexes } \\
\text { besides free cyanides }\end{array}$ & $\begin{array}{c}\text { (Kurama } \\
\text { \&.Çatalsarik, } \\
\text { 2000; Han et al, } \\
\text { 2005) }\end{array}$ \\
\hline $\begin{array}{l}\text { Gas-filled } \\
\text { membranes }\end{array}$ & $\begin{array}{l}\text { HCN transfer } \\
\text { through a gas- } \\
\text { filled hydrophobic } \\
\text { microporous } \\
\text { membranes to } \\
\text { striping solution } \\
\text { containing } \mathrm{NaOH}\end{array}$ & $\begin{array}{l}\text { Cyanide can be } \\
\text { recovered. No secondary } \\
\text { pollutants produced. } \\
\text { Energy and chemical } \\
\text { requirements are low. } \\
\text { Simple operation }\end{array}$ & $\begin{array}{l}\text { The membranes define } \\
\text { the process costs }\end{array}$ & (Han et al, 2005) \\
\hline
\end{tabular}




\begin{tabular}{|c|c|c|c|c|}
\hline $\begin{array}{l}\text { Chemical } \\
\text { precipitation }\end{array}$ & $\begin{array}{l}\text { It's recommender } \\
\text { ferrous sulfate } \\
\text { addition to the } \\
\text { cyanide-containing } \\
\text { wastewater as a } \\
\text { simple and } \\
\text { efficient treatment } \\
\text { process }\end{array}$ & $\begin{array}{c}\text { Economic for small-scale } \\
\text { operation; } \\
\text { Easy to handle by } \\
\text { unskillful labor. }\end{array}$ & Generates solid waste & $\begin{array}{c}\text { (Ismail et } \\
\text { al,2009) }\end{array}$ \\
\hline
\end{tabular}

Table 2. Cyanide removal technology (Adapted from Han et al, 2005)

\subsection{Technologies for the removal of cyanides}

As cyanides are produced regularly by industries in large quantity in waste water streams, it is a potent health hazard for human and ecosystem. Cyanides can be removed from industrial wastes by biodegradation, physical and chemical methods (Patil and Paknikar, 2000; Ebbs, 2004). There are many reported processes for treating cyanide containing effluents (Monser \& Adhoum, 2002; Dutra et al., 2008; Park et al., 2008; Mudder \& Botz, 2004; Lanza \& Bertazzoli, 2002; Han et al., 2005; Fernando et al., 2008; Yazic1, 2007; Zvinowanda et al., 2008). These processes can involve biodegradation; adsorption on activated carbon; oxidation via chemical, electrochemical or photochemical processes (Monteagudo et al., 2004; Saarela et al., 2005; Dutra et al., 2008; Lanza \& Bertazzoli, 2002; Yazic1, 2007; Monser \& Adhoum,2002); chemical precipitation (Park et al., 2008); hollow fiber gas membranes (Han et al, 2005); ultrasonic waves (Yazıc1, 2007); ion exchange (Fernando et al, 2008). The suitability of any of the above-mentioned processes to a specific cyanide-containing effluent depends on the effluent flow rate, cyanide concentration, associate chemical species, permissible level of cyanide in the effluent after treatment, technical level of the entity's employees and the economy and finances of the process.

\section{Structural characterization of the biomass}

There are several methods of elucidate the microstructure of the adsorbent materials from biomass. In this text, it will be present the most used by previous works in lignocellulosic biomass: Infrared spectroscopy (IR), X-Ray Diffraction (XRD) and Scanning Electron Microscopy (SEM). The macrocomponents which form the lignocellulosic fibers are cellulose, hemicellulose, lignin, pectin, wax and soluble substances, being the first three components responsible for the physical and mechanical proprieties of these fibers (Georgopoulos et al., 2005; Morán et al., 2008). This group includes wood agricultural crops, like jute, agricultural residues, such as sugar cane bagasse or corn stalks, banana fibers and other plant substances. Any lignocellulosic can be chemically modified (mercerization, acid treatment etc.) to enhance adsorption efficiency properties. This provides incentive for producing a variety of value-added products from different raw materials combined to provide improvements in cost or performance, or both (Gilbert, 1994).

\subsection{Infrared spectroscopy}

IR spectroscopy is a technique based on the vibrations of the atoms of a molecule. An infrared spectrum is commonly obtained by passing infrared radiation through a sample and determining what fraction of the incident radiation is absorbed at a particular energy. The goal of the basic infrared experiment is to determine changes in the intensity of a beam of infrared 


\begin{tabular}{|c|c|c|c|c|c|}
\hline $\mathrm{pH}$ & Technology & Pollutant & $\begin{array}{c}\mathrm{CN}^{-} \\
\left(\mathrm{mg} \cdot \mathrm{L}^{-1}\right)\end{array}$ & $\begin{array}{l}\text { Efficiency } \\
(\%)\end{array}$ & Reference \\
\hline 10 & $\begin{array}{l}\text { Oxidation/Application of } \\
\text { ferrate(VI) }\end{array}$ & $\begin{array}{l}\text { Cyanide-copper- } \\
\text { nickel system }\end{array}$ & 26 & 98.96 & $\begin{array}{c}\text { (Seung-Mok \& Tiwari, } \\
\text { 2009) }\end{array}$ \\
\hline 10 & $\begin{array}{l}\text { Adsorption process/pistachio } \\
\text { hull }\end{array}$ & Cyanide & 100 & 99.00 & $\begin{array}{c}\text { (Moussavi \&. Khosravi } \\
\text { et al, 2010) }\end{array}$ \\
\hline - & $\begin{array}{l}\text { Adsorption process/Modified } \\
\text { activated with carbon } \\
\text { tetrabutyl ammonium (TBA) }\end{array}$ & $\begin{array}{l}\text { Cyanide-copper- } \\
\text { zinc system }\end{array}$ & 40 & 73.00 & $\begin{array}{c}\text { (Monser \&. Adhoum et } \\
\text { al, 2002) }\end{array}$ \\
\hline- & $\begin{array}{l}\text { Adsorption process/Modified } \\
\text { activated with carbon } \\
\text { tetrabutyl ammonium (TBA) }\end{array}$ & Cyanide & 40 & 52.5 & $\begin{array}{c}\text { (Monser \&. Adhoum et } \\
\text { al, 2002) }\end{array}$ \\
\hline 11 & $\begin{array}{c}\mathrm{POA} / \mathrm{TiO}_{2} \text { and } \\
\text { 200W(of UV irradiation) }\end{array}$ & Cyanide & 26 & 99.40 & (Barak et al, 2004) \\
\hline 10 & Electrochemical processes & $\begin{array}{l}\text { Cyanide-copper } \\
\text { system }\end{array}$ & 247 & 83.40 & $\begin{array}{c}\text { (Szpyrkowicz et al, } \\
2000)\end{array}$ \\
\hline 5.3 & $\begin{array}{l}\text { Integrated coagulation-gas- } \\
\text { filled membrane absorption }\end{array}$ & Cyanide & $\begin{array}{l}1000- \\
3500\end{array}$ & $>98$ & (Shen et al, 2006) \\
\hline $9-11$ & Solvent extraction & $\begin{array}{l}\text { Cyanide-copper } \\
\text { system }\end{array}$ & 1100 & 99 & $\begin{array}{l}\text { (Alonso-González et al, } \\
\text { 2010) }\end{array}$ \\
\hline 3.2 & Adsorption process & Cyanide & - & 98 & (Moussavi ,2011) \\
\hline 8.0 & Chemical precipitation & $\begin{array}{l}\text { Cyanide-zinc } \\
\text { system }\end{array}$ & 18 & 99.47 & (Ismail et al,2009) \\
\hline
\end{tabular}

Table 3. Technologies for the removal of cyanides

radiation as a function of wavelength or frequency. The energy at which any peak in an absorption spectrum appears corresponds to the frequency of a vibration of a part of a sample molecule (Stuart, 2004). Thus, an infrared absorption spectrum of a material is obtained simply by allowing infrared radiation to pass through the sample and determining what fraction is absorbed at each frequency within some particular range (Bower \& Maddams, 2006).

Some examples of IR spectra of the lignocellulosic material are shown in Fig. 1. These samples had been studied in previous works for removal of toxic metal ions from aqueous industrial effluents or as composite materials: Sugar cane bagasse (Sousa et al., 2009) and fibers: coir (Esmeraldo et al., 2010), sisal (Barreto et al., 2009), jute (Barreto et al., 2010a) and Banana (Barreto et al., 2010b). It can be observed that the components of biomass are most likely consisted of alkenes, esters, aromatics, ketenes and alcohol, with different oxygencontaining functional groups (Yang et al., 2007). The main lignocellulosic IR vibrational modes presented are from cellulose, hemicelluloses and lignin. All samples presented two main transmittance regions. The first one at low wavelengths in the range $1800-500 \mathrm{~cm}^{-1}$ and the second one at higher wavelengths corresponding to the $3700-2750 \mathrm{~cm}^{-1}$, approximately. However, there are modification in signal intensity of these spectra due to different cellulose, hemicelluloses and lignin concentrations of each material. A resume of the assignment of main IR bands in these materials was building with dates from literature (Esmeraldo et al., 2010; Barreto et. al., 2011, Barreto et al., 2010a; Barreto et al., 2010b, Yang et al., 2007; Viera et al., 2007; Morán et al., 2008; Bilba et al., 2007) and it is presents in Table 2.

The spectrum of the Fig. 2 exhibited O-H stretching absorption of around $3430 \mathrm{~cm}^{-1}, \mathrm{C}-\mathrm{H}$ stretching absorption of around $2920 \mathrm{~cm}^{-1}, \mathrm{C}=\mathrm{C}$ benzene stretching ring of around $1634 \mathrm{~cm}^{-1}$ 
and C-O-C stretching absorption of around $1058 \mathrm{~cm}^{-1}$. There are other bands with weak and very weak signal that are described in Table 4 . These absorptions are characteristic of the common lignocellulosic fiber.

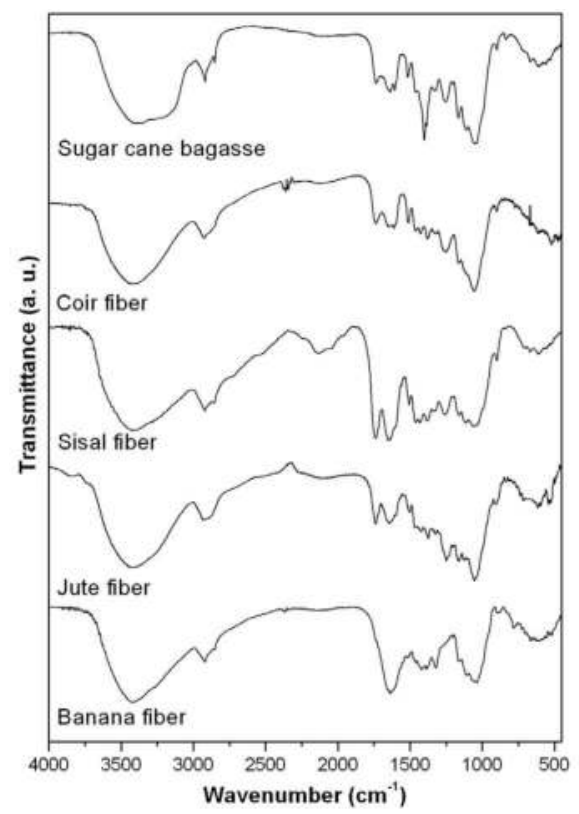

Fig. 2. Infrared spectra of natural lignocellulosic material.

\begin{tabular}{|l|l|}
\hline Wavenumber $\mathbf{( c m}^{-1} \mathbf{)}$ & Functional group \\
\hline $3600-3100$ & OH stretching \\
\hline $2970-2860$ & CH stretching of $\mathrm{CH}_{2}$ and $\mathrm{CH}_{3}$ groups \\
\hline $1765-1700$ & $\mathrm{C}=\mathrm{O}$ stretching of acetyl or carboxylic acid \\
\hline 1634 & Carbonyl stretching with aromatic ring \\
\hline $1620-1595$ & $\mathrm{C}=\mathrm{C}$ stretching of aromatic ring (lignin) \\
\hline 1512 & $\mathrm{C}=\mathrm{C}$ stretching of aromatic ring (lignin) \\
\hline 1429 & $\mathrm{CH}_{2}$ bending \\
\hline 1376 & $\mathrm{C}-\mathrm{H}$ deformation \\
\hline 1335 & OH in plane bending \\
\hline 1250 & C-O stretching of ether linkage \\
\hline 1166 & C-O-C antisymmetric bridge stretching \\
\hline 1062 & C-O symmetric stretching of primary alcohol \\
\hline 904 & $\beta-$-Glucosidic linkages between the sugar units \\
\hline $900-700$ & C-H Aromatic hydrogen (lignin) \\
\hline $700-400$ & C-C stretching (lignin) \\
\hline
\end{tabular}

Table 4. Assignment of main functional groups of lignocellusosic materials.

The infrared spectroscopy was used to analyze the effect of the chemical treatment on the surface structure of the fiber. For example, Barreto and co-workers (Barreto et. al., 2011) observed that in sisal fibers, the weight loss due to the partial dissolution of hemicellulose, 
lignin and pectin are clearly identified in the band in $1730 \mathrm{~cm}^{-1}$, which disappears when the fibers are treated by a $\mathrm{NaOH}$ aqueous solution. This vibration mode was only observed to raw sisal fibers. Another important consideration is the broadness of the hydroxyl band at 3500$3300 \mathrm{~cm}^{-1}$. For the natural sisal fibers the band is at $3419 \mathrm{~cm}^{-1}$, characteristic of the axial vibration of hydroxyls from cellulose (carbons 2, 3 and 6 of the glucose) (Esmeraldo, 2006; Calado et. al., 2000) and it is showing a broadness as a function of the chemical treatment and due to changes of the inter- and intra-molecular hydrogen bonding in polysaccharides (Esmeraldo et al., 2010), which reaches a frequency of $3372 \mathrm{~cm}^{-1}$ for the fiber treated with $\mathrm{NaOH} 10 \%$. However, for sugar cane bagasse study presents by Sousa and co-workers (Sousa et al., 2009), it was observed that acid treatment $(1.0 \mathrm{M} \mathrm{HCl})$ removed or decreased some modes of lignin: absorptions due to $\mathrm{C}-\mathrm{H}_{\mathrm{n}}$ (alkyl and aromatic) stretching vibrations (2918 and $\left.2850 \mathrm{~cm}^{-1}\right)$, absorptions characteristic of the $\mathrm{C}=\mathrm{O}$ stretching vibration $\left(1708 \mathrm{~cm}^{-1}\right)$, and a signal typical of an aromatic skeleton $\left(1604 \mathrm{~cm}^{-1}\right)$. It can also be noted that the intensities of almost all bands were lower after acid treatment. Thus, IR spectroscopy is an important tool to evaluate the changes modification of the biomass structure before and after to the chemical treatment.

\subsection{X-ray diffraction}

$\mathrm{XRD}$ is the most widely used technique for general crystalline material characterization. It is noncontact and nondestructive, which makes it ideal for in situ studies (Brundle et al., 1992). It is routinely possible to identify phases in polycrystalline bulk material and to determine their relative amounts from diffraction peak intensities. The XRD measurements are used to examining crystallite solid as ceramics, metals, geological materials, organics and polymers. The samples for measurements may be single crystals, powders, sheets, films and fibers.

Cellulose is the main renewable carbon source in nature. It presented a high organized state nature (fibrous crystal) due to its linear polymer arrange of pure anhydroglucose units connected by 1,4 $\beta$-glucosidic bonds (Chang et al., 1981). Each residue is rotated $180^{\circ}$ compared with its neighbors. The degree of polymerization (DP) of native cellulose is in the range of between 7,000 and 15,000, where DP = Molecular weight of cellulose / Molecular weight of one glucose unit. It occurs in crystal and noncrystal regions as well as in association with lignin deposition in the secondary wall. The cellulose chains are oriented in parallel and form highly organized crystalline domains interspersed by more disorganized, amorphous regions. Cellulose chains form numerous intra- and intermolecular hydrogen bonds, which account for the formation of rigid, insoluble microfibrils (Buckeridge et al., 2011). The native crystalline form has a structure designated as type I, which can be converted into type II by alkaline treatment. Fig. 3 shows a representative model of the

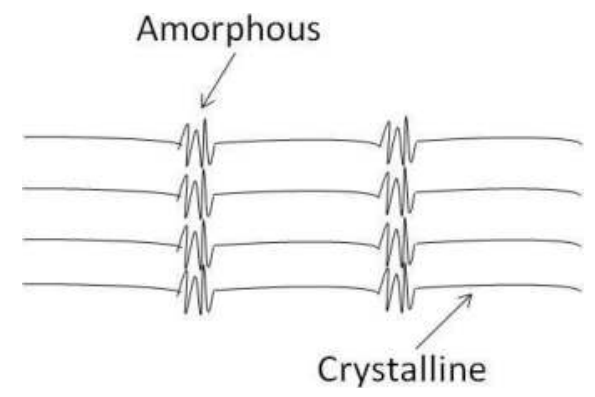

Fig. 3. Fibrillar model of cellulose. 
molecular orientation in the crystallite. One can observed that there are intermittent highly ordered areas labeled crystalline regions, separates by less ordered or amorphous regions. This characteristic is important to understand the degradation mechanism of lignocellulosic material. For instance, amorphous regions of the cellulose are first hydrolyzed followed by hydrolysis of crystalline regions at a much slower rate.

Fig. 4 shows the XRD patterns of the untreated and acid treated sugar cane bagasse. Three peaks are presented in the directions of $15.2^{0}, 16.5^{\circ}$ and $22.4^{0}$. They assign the cellulose standard profile from JCPDS (Joint Committee on Powder Diffraction Standards, 1986). Ouajai and Shanks (Ouajai \& Shanks, 2005) observed these same directions in hemp fiber and labeled them as 101, $10 \overline{1}$ and 002 diffraction planes from cellulose crystalline phase. Besides this phase, there was an amorphous phase characterized mainly as lignin. This polymer is associated to the cellular wall, conferring mechanical strength to the fiber, and when its concentration increases, the crystalline fraction decreases. The sugar cane bagasse fibers contain approximately $46 \%$ cellulose, $25 \%$ hemicelluloses and $21 \%$ lignin as the main components (Buckeridge et al., 2011). It also observed three other peaks on $26.52^{\circ}, 29.36^{\circ}$ and $30.84^{0}$ for both samples that could be attributed to impurities such as $\mathrm{SiO}_{2}$ and $\mathrm{CaCO}_{3}$, whose intensities decreased after acid treatment.

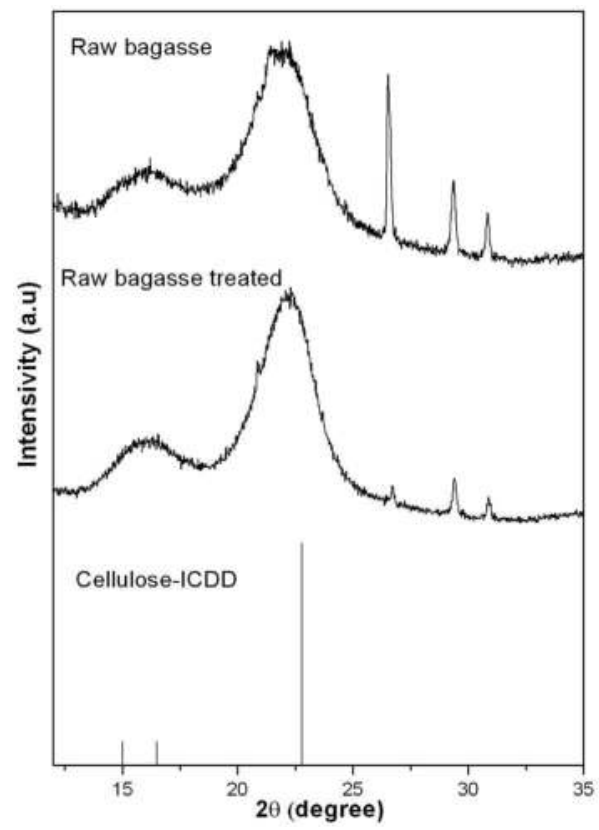

Fig. 4. XRD of the raw sugar cane bagasses and treated with $1.0 \mathrm{M} \mathrm{HCl}$, showing the crystalline and amorphous phases obtained by in comparison to data from ICDD.

The diffraction pattern from amorphous materials (including many polymers) is devoid of the sharp peaks characteristic of crystals and consists of broad features or halos. Many polymers, as biomass used to adsorbent material, are amorphous or semicrystalline, and for polymeric materials, XRD is used to clarify the structure, morphology, and degree of crystallinity. The 
sugar cane bagasse crystalline fraction $(\mathrm{F})$ can be obtained through separation and integration of crystalline and amorphous peaks areas under the diffraction X-rays plot, by the Equation (12):

$$
\mathrm{F}=\frac{\sum \mathrm{I}_{\mathrm{C}}}{\sum\left(\mathrm{I}_{\mathrm{C}}+\mathrm{I}_{\mathrm{A}}\right)} \times 100
$$

where, $I_{C}$ is the difractogram total crystalline phase area, and the $I_{A}$ is the difractogram total amorphous phase area. For XRD presented in Fig. 3, the F value for the untreated material $(62 \%)$ was close to the acid-treated material (67\%) (Sousa et al., 2009). However, depend on biomass, the $\mathrm{F}$ value can present results in different ways. As it was observed for the banana fiber (Barreto et al., 2010b): the raw material presented $63.5 \%$ and after mercerization treatment $(\mathrm{NaOH} 0.5 \%)$, this value increased to $79.2 \%$. This difference was due to the lignin be partially removed in alkaline solution, i. e., the banana fiber lost part of its amorphous component. Thus, the F values depend on the natural concentrations of lignin, cellulose and hemicelluloses presented by biomass and chemical treatment efficiency to remove amorphous phases.

\subsection{Scanning electron microscopy}

The SEM provides the investigator with a highly magnified image of the surface of a material that is very similar to what one would expect if one could actually "see" the surface visually (Brundle et al., 1992). SEM images the sample surface by scanning it with electron beams in a raster scan pattern. The electrons interact with the sample atoms producing signals that contain information about the sample's surface topography, composition and other properties such as electrical conductivity (Liu et al., 2010).

Not only is topographical information produced in the SEM, but information concerning the composition near surface regions of the material is provided as well. Additionally, the SEM can also be used to provide crystallographic information. Surfaces that to exhibit grain structure (fracture surfaces, etched, or decorated surfaces) can obviously be characterized as to grain size and shape. Thus, SEM can be used to materials characterization: topographical imaging, Energy-Dispersive X-Ray analysis and the use of backscattering measurements to determine the composition of the systems.

The surface morphology and porosity of natural fiber have been recognized as significant factors for composite interfaces, and their effects on the performance of composites have been investigated (Han \& Choi, 2010). This information about is also important for an adsorbent. It is possible observe the grain or fiber size, porosity and morphology and compare to before and after some chemical treatment employed. The increase or decrease to adsorption capacity can be the answer in this way. Thus, surface morphology and microstructure of the adsorbents can be studied by SEM. For biomass, it is necessary coat the sample with a conductor material, as gold, platinum or with a layer of carbon. This happens due to slow electron conductivity of the kind of the material and this affects the images quality.

Fig. 5(a) shows the SEM morphology at raw banana fiber. It is observed a regular structure with discrete net fibrils due to the presence of hemicelluloses, lignin, and wax, where these constituents confer mechanical strength to the natural composite. After alkali treatment 
( $\mathrm{NaOH} 1 \%)$, there is considerable structure modification as a visible separation of the fibrils, as are shown in Fig. 5(b). This happened due to remove partially of the some components. One of the aims of this treatment was to increase the surface area and decrease the hydrophilic groups. This hydrophilic nature can lead to incompatibility and poor wettability in a hydrophobic polymer matrix, and weak bonding in the fiber/matrix interface. Some cavities also appeared due to modifications on the surface.

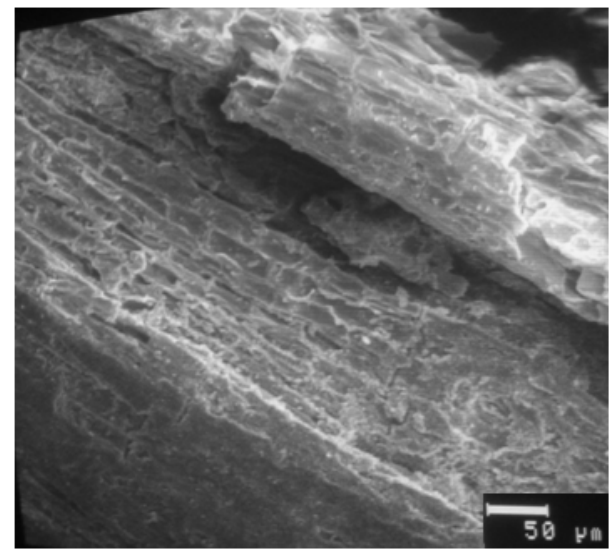

(a)

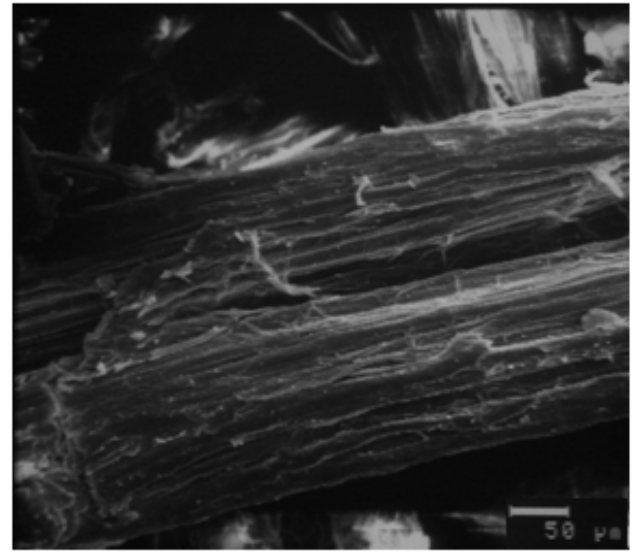

(b)

Fig. 5. SEM of the (a) raw banana fiber and (b) after alkali treatment with $\mathrm{NaOH} 1 \%$

In other example, it is presented the raw sugar cane bagasse microstructure, see Fig. 6 (a). This material presents a reasonable homogeneity in aggregate shape. However, after acid treatment with $\mathrm{HCl}$, some impurities were removed Fig. 6(b). It was also evidenced exposure and dispersion of the fibers, resulting in increased roughness. This procedure increases the superficial area of the sugar cane bagasse fiber and contributes to improve the metal adsorption capacity. Consequently, this fiber can be used as an efficient natural material to remove toxic metal ions from electroplating industry wastewater. A comparative study between metal adsorption behavior and lignocellulosic biomass morphology was

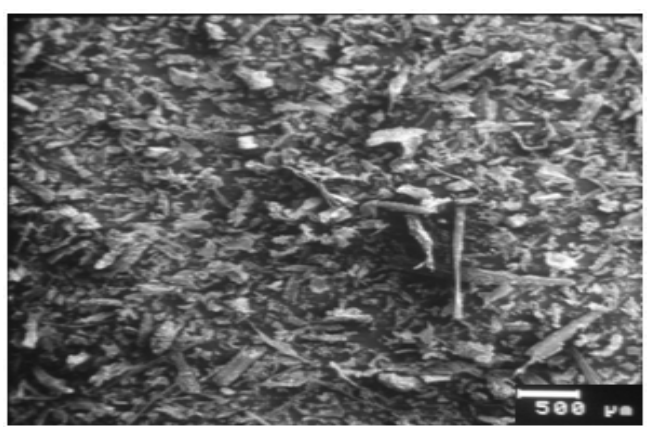

(a)

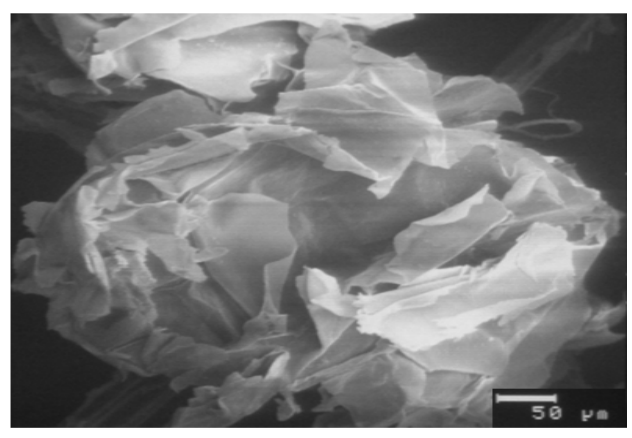

(b)

Fig. 6. SEM of the raw sugar cane bagasse (a) and after acid treatment with $\mathrm{HCl}(\mathrm{b})$. 
presented in previous studies (Bower \& Maddams, 2006; Barreto et al., 2010b). The important observation is that biomass chemical modified was more efficient than raw material in the metal removal from aqueous solution. Additionally, this kind of material, when used to adsorption material, has the advantage of low density, low cost, recyclability and biodegradability.

\section{Adsorption of single and multi-metal ions}

\subsection{Adsorption kinetics}

The study of the time dependence of adsorption on solid surface (adsorption kinetic) help in predicting the progress of adsorption in industrial application, however the determination of the adsorption mechanism is also important for design purposes. In a solid-liquid adsorption process, the transfer of the adsorbate is controlled by either boundary layer diffusion (external mass transfer) or intra-particle diffusion (mass transfer through the pores), or by both (Dabrowski, 2001). It is generally accepted that the adsorption dynamics consists of three consecutive steps:

- Transport of adsorbate from the bulk solution to the external surface of the adsorbent by diffusion through the liquid boundary layer.

- Diffusion of the adsorbate from the external surface and into the pores of the adsorbent.

- Adsorption of the adsorbate on the active sites on the internal surface of the pores.

The last step, adsorption, is usually very rapid in comparison to the first two steps. Therefore, the overall rate of adsorption is controlled by either film or intra-particle diffusion, or a combination of both. Many studies have shown that the boundary layer diffusion is the rate controlling step in systems characterized by dilute concentrations of adsorbate, poor mixing, and small particle size of adsorbent (Singh \& Mohan, 2004).

In order to investigate the adsorption kinetics of metal ions adsorption on adsorbent, pseudofirst order, pseudo-second order, and intraparticle diffusion models are the models more frequently applied, which are pseudo-first-order (Lagergren, 1898), pseudo-second-order (Ho \& Mckay, 1999) and intraparticle diffusion model (Weber \& Morris, 1963), expressed as:

$$
\begin{gathered}
\log \left(\mathrm{q}_{\mathrm{e}}-\mathrm{q}_{\mathrm{t}}\right)=\log \mathrm{q}_{\mathrm{e}}+\frac{\mathrm{K}_{1}}{2.303} \times \mathrm{t} \\
\frac{\mathrm{t}}{\mathrm{q}_{\mathrm{t}}}=\frac{1}{\mathrm{~K}_{2} \mathrm{q}_{\mathrm{e}}^{2}}+\frac{1}{\mathrm{q}_{\mathrm{e}}} \times \mathrm{t} \\
q_{t}=k_{i d} t^{1 / 2}+\mathrm{C}
\end{gathered}
$$

Where, $q_{e}$ and $q_{t}$ are the adsorption capacities $\left(\mathrm{mg} \mathrm{g}^{-1}\right)$ at the equilibrium and at a time determined, respectively, $\mathrm{t}$ the time, while $\mathrm{K}_{1}\left(\mathrm{~min}^{-1}\right)$ and $\mathrm{K}_{2}\left(\mathrm{mg} \mathrm{g}^{-1} \mathrm{~min}^{-1}\right)$ are rate constants related to the first order and second order models. $C$ is the intercept and $k_{i d}$ is the intraparticle diffusion rate constant $\left(\mathrm{mg} \mathrm{g}^{-1} \mathrm{~min}^{-1 / 2}\right)$, which can be evaluated from the slope of the linear plot of $q_{t}$ versus $t^{1 / 2}$. The values $C$ provide information about the thickness of the boundary layer, the larger the intercept, the greater the boundary layer effect (Kavitha \& Namasivayam, 2007). 
If intra-particle diffusion occurs, then $\mathrm{q}_{\mathrm{t}}$ versus $\mathrm{t}^{1 / 2}$ will be linear and if the plot passes through the origin, then the rate limiting process is only due to the intra-particle diffusion. Otherwise, some other mechanism along with intra-particle diffusion is also involved.

The typical results obtained by Sousa et al., 2010; Moreira et al., 2010 for the metal ions sorption onto lignocellusic adsorbents by investigating the pseudo first and pseudo-secondorder rate equations order and intraparticle diffusion model are presented in Table 5. Applications of these rate equations for describing the kinetics studies were investigated for batch technique due its simplicity. For this, erlenmeyer flasks of $50 \mathrm{~mL}$ containing $0.30 \mathrm{~g}$ of adsorbent with $10 \mathrm{~mL}$ of multi-metal solution (100 $\mathrm{mg} \mathrm{L}^{-1}$, at $\left.\mathrm{pH} 5.0\right)$ were shaken (at 300 $\mathrm{rpm}$ ) in room temperature, at $28^{\circ} \mathrm{C}$. After a predetermined time, volumes of the solution were removed, filtrated and analyzed. The amount of adsorption was calculated at equilibrium achieved in $4-5 \mathrm{~h}$ by equation 16 .

$$
\mathrm{qe}_{\mathrm{e}}=\frac{\left(\mathrm{C}_{\mathrm{o}}-\mathrm{C}_{\mathrm{e}}\right) \mathrm{V}}{\mathrm{m}}
$$

Where: $C_{o}$ is the solution initial concentration $\left(\mathrm{mg} \mathrm{L}^{-1}\right) ; C_{e}$ is the equilibrium concentration of adsorbate (mg L-1); $V$ is the solution volume $(\mathrm{L})$ and $m$ is the mass do adsorbent $(\mathrm{g})$.

The linear plot of $\log \left(\mathrm{q}_{\mathrm{e}}-\mathrm{q}_{\mathrm{t}}\right)$ versus $\mathrm{t}$ for pseudo first order, $1 / \mathrm{q}$ versus $\mathrm{t}$ for pseudo-second order and q versus $\mathrm{t}^{1 / 2}$ for intraparticle diffusion models are used for constants $K_{1}, K_{2}$ and $K_{f}$ calculated from slope of the corresponding linear equations and correlation coefficients $\left(\mathrm{R}^{2}\right)$. From results presented in Table 5 can be noted that the experimental $\mathrm{q}_{\mathrm{e}}$ values show a reasonable agreement with the calculated $\mathrm{q}_{\mathrm{cal}}$ value by first order equation, indicating that the adsorption system belongs to the first order reaction. In contrast, do not agree between experimental and calculated qcal values by second-order equation is observed. This indicates that the adsorption of multi-metal on the sugar cane bagasse is not described by a second order reaction.

When the intraparticle diffusion model can be applied then the plots of $q$ versus $\mathrm{t}^{1 / 2}$ is linear, and if it passes thought the origin the limiting processes is only due to intraparticle diffusion (Weber \& Morris, 1963). However, since that the plots of $q$ versus $t \frac{1}{2} 2$ (not showed) was linear but is not pass through origin, then the intraparticle diffusion is not the only rate limiting mechanism on multi-metal adsorption on the cane sugar bagasse studied.

Table 5 presented the results obtained of adsorption kinetics studies for $\mathrm{Cu}^{2+}-\mathrm{Ni}^{2+}-\mathrm{Cd}^{2+}$ on the sugar cane bagasse (Sousa et al.,2010). It is observed that the experimental $\mathrm{q}_{\mathrm{e}}$ values are reasonable in agreement with the calculated $\mathrm{q}_{\mathrm{c}}$ value for first order equation, indicating that the adsorption system belongs to the first order reaction. In contrast, do not agree between experimental and calculated $\mathrm{q}_{\mathrm{e}}$ values by second-order equation can be observed. This suggest that adsorption of $\mathrm{Cu}^{2+-} \mathrm{Ni}^{2+}-\mathrm{Cd}^{2+}$ on the sugar cane bagasse not follows a second order reaction. However, the results found by Moreira et al., 2010 showed that $\mathrm{Cu}^{2+}, \mathrm{Ni}^{2+}$ and $\mathrm{Cd}^{2+}$ adsorption on cashew bagasse has a good agreement between the experimental $\left(q_{e}\right)$ and the calculated $\left(q_{c a}\right)$ values, as shown in Table 5 . The high values for coefficient of correlation, $R^{2}$, indicate that there is strong evidence that the $\mathrm{Cu}^{2+}, \mathrm{Ni}^{2+}$ and $\mathrm{Cd}^{2+}$ adsorption onto cashew bagasse follows the pseudo- first and second order kinetic models.

When the intraparticle diffusion model can be applied then the plots of $q$ versus $t^{1 / 2}$ is linear, and if it passes thought the origin the limiting processes is only due to intraparticle diffusion 
(Weber \& Moris, 1963). However, since that the plots of $q$ versus $t^{1} \frac{1}{2}$ (not showed) was linear but is not pass through origin, then the intraparticle diffusion is not the only rate limiting mechanism on multi-metal adsorption on the cane sugar and cashew bagasse studied. The values correlation coefficient $\left(\mathrm{R}^{2}\right)$ obtained for the plots were not satisfactory.

\begin{tabular}{|c|c|c|c|c|c|c|c|c|c|c|}
\hline \multirow[b]{2}{*}{ Metal } & \multirow[b]{2}{*}{$\begin{array}{c}C_{o} \\
\left(\mathrm{mg} \mathrm{L}^{-1}\right)\end{array}$} & \multirow[b]{2}{*}{$\begin{array}{c}q_{e(\exp )} \\
(\mathrm{mg} g-1)\end{array}$} & \multicolumn{3}{|c|}{ First order } & \multicolumn{3}{|c|}{ Second order } & \multicolumn{2}{|c|}{$\begin{array}{c}\text { Intraparticle } \\
\text { Diffusion }\end{array}$} \\
\hline & & & $\begin{array}{c}\boldsymbol{q}_{(\mathrm{cal})} \\
\left(\mathrm{mg} \mathrm{g}^{-1}\right)\end{array}$ & $\begin{array}{c}K_{1} \\
\left(\min ^{-1}\right)\end{array}$ & $R^{2}$ & $\begin{array}{c}\boldsymbol{q}_{(\mathrm{cal})} \\
\left(\mathrm{mg} \mathrm{g}^{-1}\right)\end{array}$ & $\begin{array}{c}K_{2} \\
\left(\mathrm{mg} \mathrm{g}^{-1} \min ^{-1}\right)\end{array}$ & $R^{2}$ & $\begin{array}{c}K_{f} \\
\left(\mathrm{mg} \mathrm{g}^{-1}\right. \\
\left.\min ^{-1 / 2}\right)\end{array}$ & $R^{2}$ \\
\hline & & & & \multicolumn{2}{|c|}{$\begin{array}{c}\text { sugar cane } \\
\text { bagasse }\end{array}$} & & & & & \\
\hline $\mathrm{Cu}^{2+}$ & 74.14 & 2.015 & 2.01 & 0.98 & 0.890 & 3.11 & 0.140 & 0.88 & 0.79 & 0.860 \\
\hline $\mathrm{Ni}^{2+}$ & 108.81 & 0.827 & 1.05 & 0.61 & 0.890 & - & - & - & 0.29 & 0.810 \\
\hline \multirow[t]{2}{*}{$\mathrm{Cd}^{2+}$} & 117.99 & 2.54 & 2.56 & 0.51 & 0.920 & 5.44 & 0.040 & 0.93 & 0.51 & 0.860 \\
\hline & & & & \multicolumn{2}{|c|}{$\begin{array}{l}\text { Cashew } \\
\text { bagasse }\end{array}$} & & & & & \\
\hline $\mathrm{Cu}^{2+}$ & 102.18 & 1.982 & 1.933 & 0.016 & 0.956 & 1.95 & 0.518 & 1.00 & 0.009 & 0.779 \\
\hline $\mathrm{Ni}^{2+}$ & 82.93 & 1.588 & 1.573 & 0.006 & 0.790 & 1.59 & 0.873 & 1.00 & 0.003 & 0.755 \\
\hline $\mathrm{Cd}^{2+}$ & 90.70 & 1.803 & 1.800 & 0.012 & 0.852 & 1.80 & 0.022 & 1.00 & 0.001 & 0.909 \\
\hline
\end{tabular}

Table 5. Parameter of adsorption kinetic in the sugar cane bagasse and cashew bagasse in multi-metal solutions (10-200 mg.L-1) at $\mathrm{pH} 5.0$, time equilibrium achieved in 4-5 h.

\subsection{Adsorption isotherm equilibrium}

Most experimental and theoretical studies of the adsorption at solid-liquid interface have been carried for single or multi metal ions removal from aqueous solution by diverse types of low cost adsorbents (Pasavant et al., 2006; Aksu et al.,2002; Cay et al., 2004; Amarasinghe \& Williams, 2007). In the practice, the adsorption metal ions from wastewater generally involve the simultaneous presence of metal ions in wastewater promoting a competition between different metal ions by adsorption site. However, study of equilibrium modeling of multimetal ions is essential for understand the real system, but usually are neglected (Febrianto, 2009).

Adsorption is an important process that describes the interaction between adsorbent and metal ion to develop design model for wastewater industrial treatment. The applicability of relationship between the experimental adsorption capacities and the metal ions concentrations (adsorption isotherm) have been widely used by the Langmuir and Freundlich models (Frebianto et al., 2009).

\subsubsection{Langmuir model}

The Langmuir adsorption model is based on the assumption that maximum adsorption corresponds to a saturated monolayer of solute molecules on the adsorbent surface, with no lateral interaction between the adsorbed metal. The Langmuir adsorption isotherm model is successfully used to explain the metal ions adsorption from aqueous solutions (Langmuir, 1918). The expression of the Langmuir model is given by Eq.(17), 


$$
\mathrm{q}_{\mathrm{e}}=\frac{\mathrm{q}_{\max } \cdot \mathrm{K}_{\mathrm{L}} \cdot \mathrm{C}_{\mathrm{e}}}{\left(1+\mathrm{K}_{\mathrm{L}} \mathrm{C}_{\mathrm{e}}\right)}
$$

and the linearized Lagmuir isotherm equation can be expressed as:

$$
\frac{1}{\mathrm{q}_{\mathrm{e}}}=\frac{1}{\mathrm{q}_{\max }}+\left(\frac{1}{\mathrm{q}_{\max } \mathrm{K}_{\mathrm{L}}}\right)\left(\frac{1}{\mathrm{C}_{\mathrm{e}}}\right)
$$

\subsubsection{Freundlich model}

The Freundlich isotherm gives the relationship between equilibrium liquid and solid phase capacity based on the multilayer adsorption (heterogeneous surface). This isotherm is derived from the assumption that the adsorption sites are distributed exponentially with respect to the heat of adsorption and is given by Freundlich, 1906).

The Freundlich isotherm is an empirical equation employed to describe heterogeneous systems. The Freundlich equation is expressed as:

$$
\mathrm{q}_{\mathrm{e}}=\mathrm{K}_{\mathrm{F}} \mathrm{C}_{\mathrm{e}}{ }^{1 / \mathrm{n}}
$$

and linearized Freundlich isotherm equation can be expressed as:

$$
\log \mathrm{q}_{\mathrm{e}}=\log \mathrm{K}_{\mathrm{F}}+1 / \mathrm{n} \log \mathrm{C}_{\mathrm{e}}
$$

Where $\mathrm{q}_{\mathrm{e}}$ (mg.g-1) is the amount of metal ion adsorbed, expressed as mg metal ions per $\mathrm{g}$ adsorbent, $\mathrm{C}_{\mathrm{e}}\left(\mathrm{mg} \cdot \mathrm{mL}^{-1}\right)$ the equilibrium concentration of metal ion in solution, $\mathrm{q}_{\max }(\mathrm{mg} \cdot \mathrm{g}-1)$ and $\mathrm{K}_{\mathrm{L}}\left(\mathrm{L} \cdot \mathrm{mg}^{-1}\right)$ are constants of Langmuir related to the maximum adsorption capacity (mg.g1) and heat of adsorption, respectively, while $K_{F}\left(\mathrm{mg}^{1-(1 / n)} \cdot\left(\mathrm{g}^{-1}\right) \cdot \mathrm{L}^{1 / n}\right)$ and $1 / \mathrm{n}$ are constants of Freundlich related to the adsorption capacity and to surface heterogeneity, respectively.

\subsubsection{Applications of Langmuir and Freundlich models}

The linear fit of the experimental data using the Langmuir and Freundlich models permitted to obtain correlation coefficients greater than 0.90 . Although its satisfactory value indicate, the applicability of both models is very difficult to identify the adsorption equilibrium model which represented the experimental data most correctly considering only the correlation coefficients. Hence, a parameter known as normalized percent deviation, $\mathrm{P}$, (Ayranci, 2005) can be applied, according to the following equation 21:

$$
\mathrm{P}=(100 / \mathrm{N}) \sum\left(\left|\mathrm{q}_{\mathrm{e}}-\mathrm{q}_{\mathrm{cal}}\right| / \mathrm{q}_{\mathrm{e}}\right)
$$

where $\mathrm{q}_{\mathrm{e}}$ is the experimental adsorption capacity, $\mathrm{q}_{\mathrm{cal}}$ the predicted adsorption capacity, and $\mathrm{N}$ the number of observations. The lower the $\mathrm{P}$ value is, better the fit is.

According to the literature (Cooney, 1993), the slope of the initial curvature of an adsorption isotherm indicates whether or not an adsorption system is efficient, which, for a Langmuir isotherm, can be expressed in terms of the separation factor $\mathrm{R}_{\mathrm{L}}$ (Cooney, 1993; Ngah et al, 2008):

$$
\mathrm{R}_{\mathrm{L}}=1 /\left(1+\mathrm{K}_{\mathrm{L}} \mathrm{C}_{\mathrm{o}}\right)
$$


where $\mathrm{K}_{\mathrm{L}}\left(\mathrm{L} \mathrm{mg}^{-1}\right)$ is the Langmuir constant and $\mathrm{C}_{\mathrm{o}}$ the metal ion initial concentration.

The type of isotherm is considered to be unfavorable, i.e., the solute has a preference for adsorption to the solid phase over dissolution in the liquid phase $\left(R_{L}>1\right)$, linear $\left(R_{L}=1\right)$, favorable $\left(0<R_{L}<1\right)$ or irreversible $\left(R_{L}=0\right)$ depending on the value of $R_{L}$ (Cooney, 1993, Ngah et al, 2008). The experimental $R_{L}$ values were between 0 and 1 for all initial concentrations as known in Tables 6 and 7, hence, adsorption of metals ions studied on the adsorbent is considered to be favorable.

Applications of Langmuir and Freundlich models for describing adsorption isotherms with green coconut shell powder and cane sugar bagasse (treated with sodium hydroxide) for toxic metals removal from aqueous effluents were studied (Sousa et al., 2011; Sousa et al., 2010). Equilibrium adsorption isotherms of multi-metal $\left(\mathrm{Cd}^{+2}-\mathrm{Cu}^{+2}-\mathrm{Ni}^{+2}-\mathrm{Pb}^{+2}-\mathrm{Zn}^{+2}\right)$ on the green coconut shells and cane sugar bagasse are given in Fig. 7. The parameters of Langmuir $\left(K_{L} ; q_{\max }\right)$ and Freundlich $\left(K_{F} ; 1 / n\right)$, determined from the slope and intercept of the plots of $1 /$ $\mathrm{q}_{\mathrm{e}}$ versus $1 / \mathrm{C}_{\mathrm{e}}$ and $\log \mathrm{q}_{\mathrm{e}}$ versus $\log \mathrm{C}_{\mathrm{e}}$ are shown in Tables 6 and 7.
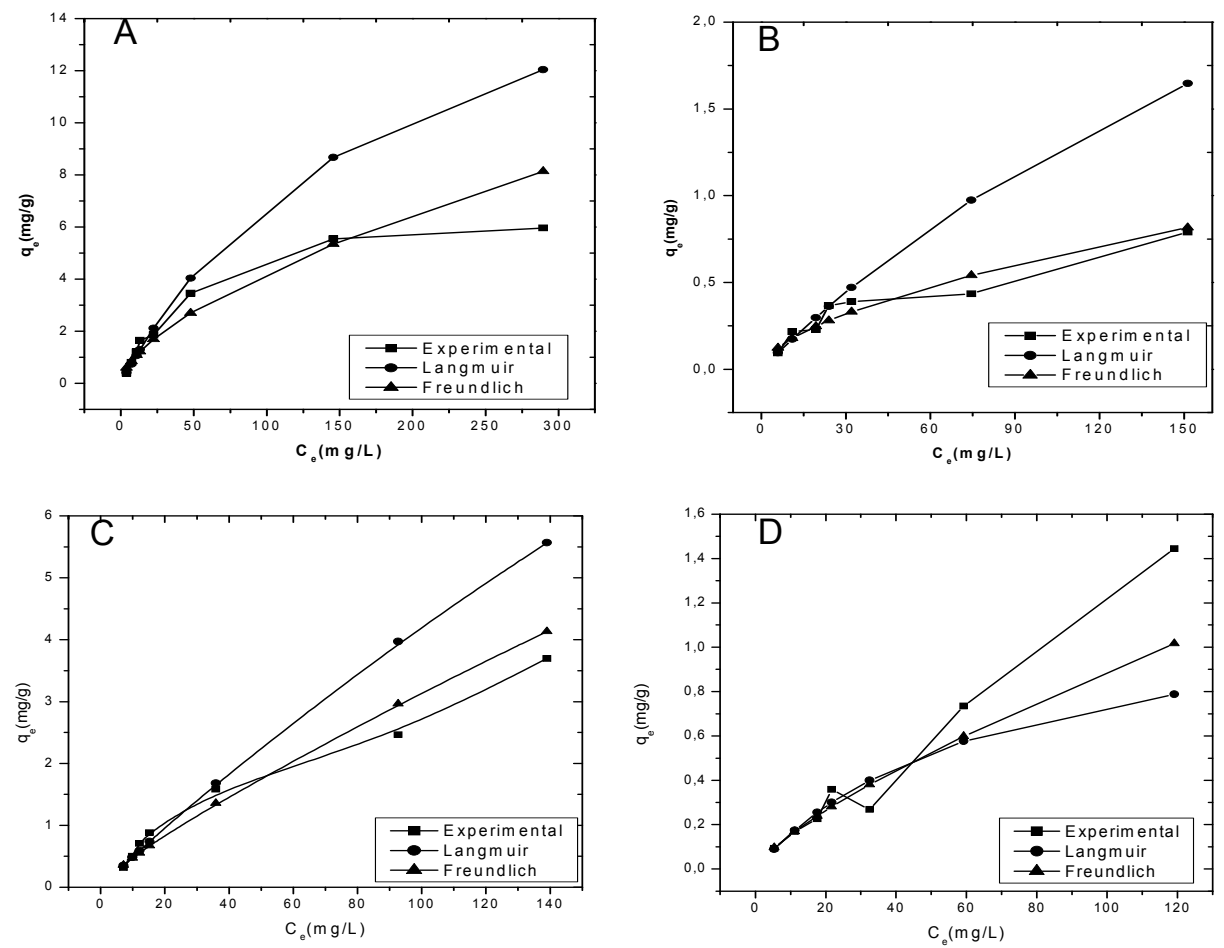

Fig. 7. Adsorption isotherm to metal ions: $\mathrm{Pb}^{+2}(\mathrm{a}), \mathrm{Cd}^{+2}(\mathrm{~b}), \mathrm{Cu}^{+2}(\mathrm{c})$ and $\mathrm{Ni}^{+2}(\mathrm{~d})$ on sugar cane bagasse, contact time $24 \mathrm{~h}$ and $\mathrm{pH} 5.0$.

The $\mathrm{P}$ values calculated in according to the Langmuir and Freundlich equations for single and multi-systems for sugar cane bagasse are given in Tables 6 . It is observed that for single metal ion system the $\mathrm{P}$ deviations are lowest when the experimental data were fitted to the 
Langmuir equation for all single metal ions studied, while the Freundlich model proved suitable for multi-metal system

The Langmuir and Freundlich isotherms for multi-metal ions adsorption on green coconut shell powder are shown in Fig. 8. The parameters determined for single and multi-metal ions each model are given in Table 3. The experimental data show that the Langmuir-type isotherms describe well the adsorption mechanism for $\mathrm{Pb}^{+2}, \mathrm{Ni}^{+2}$ and $\mathrm{Cd}^{+2}$, while $\mathrm{Zn}^{+2}$ and $\mathrm{Cu}^{+2}$ are of the Freundlich-type as can be observed by the values of correlation coefficients $\left(R^{2}\right)$. The adsorption capacity of the multi-metals studied followed the order: $\mathrm{Zn}^{+2}>\mathrm{Pb}^{+2}>$ $\mathrm{Cu}^{+2}>\mathrm{Cd}^{+2}>\mathrm{Ni}^{+2}$. This can be attributed to the specificity of active sites, to varying affinities for adsorption or to competitive effects. Sekhar et al., 2003 referred that multicomponent systems, the complex interactions of several factors such as ionic charge and ionic radii will account for the differences in the metal removal capacity of the adsorbent. As a result, ordering of the metal ions based on a single factor is very difficult.
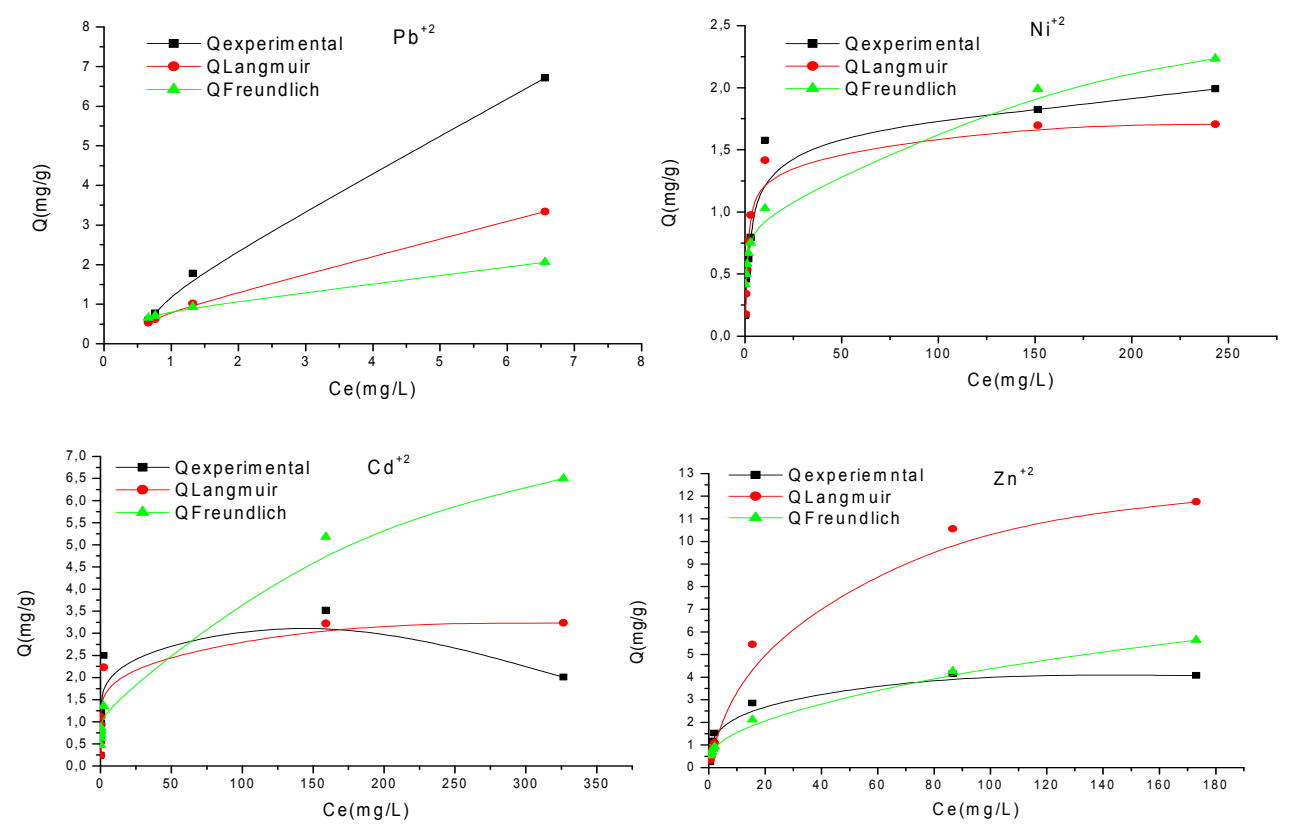

Fig. 8. Comparison of the Langmuir and Freundlich models with the experimental isotherm for $\mathrm{Pb}^{+2}, \mathrm{Ni}^{+2}, \mathrm{Cd}^{+2}$ and $\mathrm{Zn}^{+2}$ in a multimetal solution on green coconut shell powder treated with $\mathrm{NaOH} 0.1$ mol.L-1/3 h, pH 5, $C_{\text {biomass }}=40$ g.L-1, particle size 60-99 mesh, ambient temperature $(28 \pm 2 \circ \mathrm{C})$.

The experimental data for single systems clearly show that the Langmuir-type isotherms describe well the adsorption mechanism $\mathrm{Pb}^{+2}, \mathrm{Cd}^{+2}$ and $\mathrm{Cu}^{+2}$, while $\mathrm{Zn}^{+2}$ is of the Freundlich-type. On the other hand, $\mathrm{Ni}^{+2}$ agrees well with both models. The adsorption capacity of the single metals studied followed the order: $\mathrm{Cd}^{+2}>\mathrm{Zn}^{+2}>\mathrm{Cu}^{+2}>\mathrm{Pb}^{+2}>\mathrm{Ni}^{+2}$, which can be correlated to the ionic radius of Pauling, except for $\mathrm{Pb}^{+2}$ and $\mathrm{Ni}^{+2}$ (Table 2) (Vázques et al., 2002; Mohan \& Singh, 2002; Sekhar et al., 2003; Mattuschka \& Straube, 1993). 
The values of $R_{L}$ for single and multi-metal ions are all between 0 and 1 indicating that adsorption on green coconut shell powder is very efficient for these systems (Table 4).

\begin{tabular}{|c|c|c|c|c|c|c|c|c|c|}
\hline \multirow[t]{2}{*}{ Metal ions } & \multicolumn{5}{|c|}{ Langmuir } & \multicolumn{4}{|c|}{ Freundlich } \\
\hline & $\begin{array}{c}\mathrm{K}_{\mathrm{L}} \\
\left(\mathrm{L} \mathrm{mg}^{-1}\right)\end{array}$ & $\begin{array}{c}q_{\max } \\
\left(\mathrm{mg} \mathrm{g}^{-1}\right)\end{array}$ & $R_{L}$ & $P$ & $R^{2}$ & $\begin{array}{c}K_{F}\left(\mathrm{mg}^{1-(1 / n)}\right) \\
\left.\left(\mathrm{g}^{-1}\right) \mathrm{L}^{1 / n}\right)\end{array}$ & $1 / n$ & $P$ & $R^{2}$ \\
\hline \multicolumn{10}{|l|}{ Single metal } \\
\hline $\mathrm{Cu}^{+2}$ & 0.006 & 7.34 & $0.400-0.952$ & 8.52 & 0.98 & 0.072 & 0.82 & 12.73 & 0.96 \\
\hline $\mathrm{Ni}^{+2}$ & 0.015 & 1.23 & $0.214-0.891$ & 9.22 & 0.97 & 0.028 & 0.76 & 10.89 & 0.93 \\
\hline $\mathrm{Pb}^{+2}$ & 0.005 & 19.92 & $0.291-0.925$ & 10.26 & 0.98 & 0.253 & 0.61 & 17.14 & 0.93 \\
\hline $\mathrm{Cd}^{+2}$ & 0.002 & 1.07 & $0.180-0.868$ & 9.20 & 0.95 & 0.044 & 0.58 & 16.62 & 0.90 \\
\hline \multicolumn{10}{|l|}{ Muti-metal } \\
\hline $\mathrm{Cu}^{+2}$ & 0.06 & 1.10 & $0.062-0.689$ & 18.97 & 0.89 & 0.080 & 0.64 & 21.54 & 0.77 \\
\hline $\mathrm{Ni}^{+2}$ & 0.03 & 0.59 & $0.082-0.939$ & 26.14 & 0.54 & 0.009 & 0.97 & 20.46 & 0.89 \\
\hline $\mathrm{Pb}^{+2}$ & 0.062 & 12.66 & $0.614-0.979$ & 23.58 & 0.74 & 0.009 & 1.00 & 18.77 & 0.65 \\
\hline $\mathrm{Cd}^{+2}$ & 0.002 & 1.17 & 0.158-0849 & 29.20 & 0.66 & 0.044 & 0.58 & 16.62 & 0.91 \\
\hline
\end{tabular}

$R_{L}=$ separation factor

Table 6. Adsorption isotherms parameters of Langmuir and Freundlich, for single-metal adsorbed on sugar cane bagasse.

\begin{tabular}{cccccccc}
\hline Adsorption & \multicolumn{3}{c}{ Langmuir } & \multicolumn{3}{c}{ Freundlich } \\
\cline { 2 - 8 } & $\begin{array}{c}K_{F}\left(\mathrm{mg}^{1-(1 / \mathrm{n})}\right. \\
\left.\left(\mathrm{g}^{-1}\right) \mathrm{L}^{1 / \mathrm{n}}\right)\end{array}$ & $\boldsymbol{q}_{\max }\left(\mathbf{m g}^{-1}\right)$ & $\boldsymbol{R}_{\boldsymbol{L}}$ & $\boldsymbol{R}^{2}$ & $\begin{array}{c}\boldsymbol{K}_{F}\left(\mathrm{mg}^{1-(1 / \mathrm{n})}\right. \\
\left.\left(\mathrm{g}^{-1}\right) \mathrm{L}^{1 / \mathrm{n}}\right)\end{array}$ & $\mathbf{1 / n}$ & $\boldsymbol{R}^{\mathbf{2}}$ \\
\hline $\begin{array}{c}\text { ingle metal } \\
\mathrm{Cu}^{+2}\end{array}$ & 0.072 & 10.45 & $0.441-0.013$ & 0.994 & 0.767 & 0.614 & 0.958 \\
$\mathrm{Ni}^{+2}$ & 0.110 & 6.71 & $0.339-0.010$ & 0.986 & 0.685 & 0.547 & 0.986 \\
$\mathrm{~Pb}^{+2}$ & 0.086 & 8.32 & $0.560-0.01$ & 0.986 & 0.814 & 1.492 & 0.925 \\
$\mathrm{Cd}^{+2}$ & 0.085 & 17.51 & $0.865-0.154$ & 0.979 & 1.315 & 0.669 & 0.880 \\
$\mathrm{Zn}^{+2}$ & 0.072 & 10.45 & $0.697-0.060$ & 0.994 & 0.767 & 0.614 & 0.958 \\
Multi- metal & & & & & & & \\
$\mathrm{Cu}^{+2}$ & 0.227 & 5.09 & $0.354-0.004$ & 0.969 & 0.834 & 0.581 & 0.977 \\
$\mathrm{Ni}^{+2}$ & 0.451 & 1.72 & $0.241-0.003$ & 0.967 & 0.580 & 0.245 & 0.900 \\
$\mathrm{~Pb}^{+2}$ & 0.112 & 7.89 & $0.560-0.008$ & 0.972 & 0.812 & 0.497 & 0.886 \\
$\mathrm{Cd}^{+2}$ & 0.962 & 3.24 & $0.098-0.001$ & 0.991 & 1.04 & 0.315 & 0.759 \\
$\mathrm{Zn}^{+2}$ & 0.045 & 13.3 & $0.677-0.025$ & 0.896 & 0.877 & 0.341 & 0.903 \\
\hline
\end{tabular}

Table 7. Adsorption isotherms parameters of Langmuir and Freundlich, with the correlation coefficients $\left(R^{2}\right)$ for single and multi-metal adsorbed on coconut shells bagasse.

\subsubsection{Prediction of multi metal equilibrium}

In the practice, the adsorption metal ions from wastewater generally involve the simultaneous presence of metal ions in wastewater promoting a competition between different metal ions by adsorption site. However, study of equilibrium modeling of multimetal ions is essential for understand the real system, but usually are neglected (Frebianto, 
2009). The competitive adsorption of metal ions on the sugar cane bagasse was studied (Sousa et al., 2011) using the extended Langmuir model, expressed as:

$$
q_{i}=\frac{q_{m} K_{i} C_{i}}{1+\sum_{j=1}^{n} K_{j} C_{j}}
$$

for $i=1,2, \ldots, n$, where $i$ and $j$ represent the metal ions, $q_{i}$ and $q_{m}$ they are the adsorption capacity and maximum capacity of adsorption (mg metal / g adsorbent) and K Langmuir constant.

Considering that a solid adsorbent has a given surface area, then the presence of other solutes implies a competition for available adsorption sites. In general, the presence of other solutes decreases the adsorption of any given solute (Cooney, 1993). Based on the isotherms showed in Fig. $9(a, b)$ can be seen that there is a substantial difference between predicted and experimental values indicating a considerable effect of competition by metals adsorption sites. The results showed in Figure 8 prove competition for binding sites from comparison of the experimental and predicted data. Thus, adsorption is not specific and limited to a maximum binding capacity.
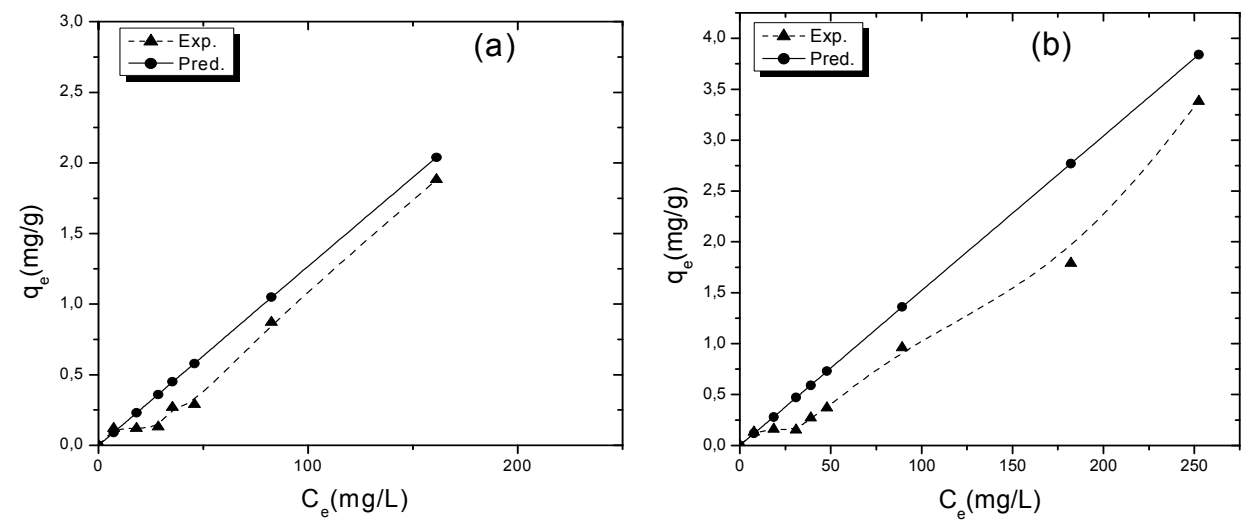

Fig. 9. Comparison between the experimental and predicted adsorption models for $\mathrm{Ni}^{+2}$ (a) and $\mathrm{Cd}^{+2}($ b) on cane sugar bagasse treated with $\mathrm{NaOH} 0.1 \mathrm{~mol} . \mathrm{L}-/ 3 \mathrm{~h}$, in a multimetal solution. Conditions: $\mathrm{pH} 5, \mathrm{C}_{\text {biomass }}=40 \mathrm{~g} \cdot \mathrm{L}^{-1}$, ambient temperature $\left(28 \pm 2{ }^{\circ} \mathrm{C}\right)$.

\subsection{Adsorption in fixed bed - column}

\subsubsection{Breakthrough curves theory}

The majority of adsorption studies have been carried out in the batch mode, but a fixed bed conventional system (column) should be economically most valuable for wastewater treatment (Cooney, 1999). A system of fixed bed conventional is compound of a column which particles of the bioadsorbent are putting in contact with the effluent. The column efficiency is described through of the concept of breakthrough curve. An ideal breakthrough curve is show in the Fig. 10, where $C_{o}$ and $V_{e}$ are the adsorbate concentration in the effluent and the volume of effluent passed in the column, respectively. The ideal curve admits that the adsorbate removal is complete above of the initial stages of operation. In this curve the breakpoint has been chosen arbitrarily at $C_{b}$ and occur when the effluent concentration 
reached $5 \%$ of the initial concentration $C_{0}$. The column reaches the complete saturation when the concentration $C_{x}$, closely approaching $C_{o}$. The total amount of effluent, $V_{b}$, passed in the column until the breakpoint and the nature of the breakthrough curve between the values of $V_{b}$ and $V_{x}$ are important to design of a column (Cooney, 1999).

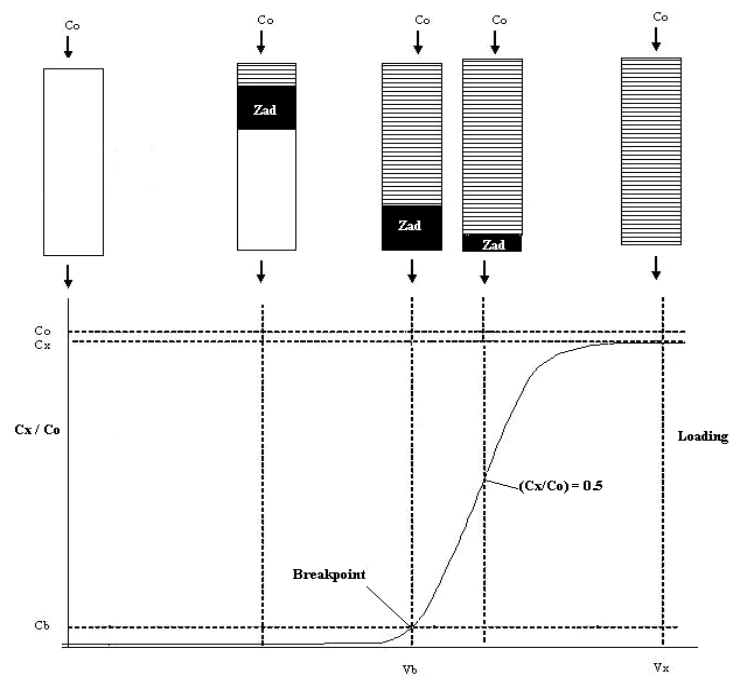

Fig. 10. Ideal breakthrough curve. (Adaptaded from Cooney, D.O.(1999). Adsorption design for wastewater treatment, Lewis publishers, ISBN 1566703336 9781566703338. Boca Raton, Fl and McKay, G. (1996) (Editors), Design of adsorption contatacting systems,in: Use of Adsorbents for the Rremoval of Pollutans from Wasterwaters,pp 99-131,CRC press,Inc, Boca Raton, Florida ISBN: 0-8493-6920-7

The part between $C_{x}$ (exhaustion point) and $C_{b}$ (breakpoint) is called the primary adsorption zone (PAZ) and the time needed for PAZ to move down the column is calculated by Equation 24 (Gupta et al., 1997; 2000; Kundu \& Gupta, 2005):

$$
t_{x}=\frac{V_{x}}{F_{m}}
$$

Where, $t_{x}$ is the time to establish PAZ ( $\left.\mathrm{min}\right), F_{m}$ is the flow rate $(\mathrm{mL} / \mathrm{min})$ and $V_{x}$ is the exhaustion volume $(\mathrm{mL})$.

The maximum capacity of removal of toxic metal ions in the column is given by Equation 25 (Gupta et al., 1997; 2000; Kundu \& Gupta, 2005):

$$
\mathrm{Q}=\frac{\mathrm{C}_{0} * \mathrm{~V}}{\mathrm{~m}_{\mathrm{s}}} \int_{\mathrm{t}=0}^{\mathrm{t}=\mathrm{x}}\left(1-\frac{\mathrm{C}}{\mathrm{C}_{0}}\right) \mathrm{dt}
$$

Where, $Q$ is the maximum adsorption capacity $(\mathrm{mg} / \mathrm{g}) ; C_{0}$ and $C$ are the initial concentration of the solution and the concentration of the metal ion in a determined volume $(\mathrm{mg} / \mathrm{L})$, respectively; $m_{s}$ is the mass of the adsorbent $(\mathrm{g}) ; V$ is the flow rate $(\mathrm{L} / \mathrm{min})$ and $\mathrm{t}$ is the time in minutes. 


\subsubsection{Breakthrough curves}

Metal cyanides can occur of various forms in the wastewaters, generated from electroplating industries, depending of the solution pH (Patil \& Paknikar, 1999; Bose et al., 2002). For wastewaters containing high copper concentration and relative concentration of zinc, nickel and cyanide, the weak complexes of nickel and zinc are present in negligible concentrations. In contrast, copper-cyanide complexes are present in appreciable quantity, due to high affinity of copper by cyanide (Bose et al., 2002).

Since the electroplating wastewater contains metal-cyanide complexes, thus the influence of these species on metal ions removal of wastewater using sugar cane bagasse have been studied (Sousa et al., 2010). For this, the breakthrough curves were investigated for synthetic effluent spiked with amount known of copper, nickel and cyanide ions similarly to the effluent industrial composition. The synthetic samples were treated by alkaline chlorination for destruction of cyanide (Akcil, 2003). The treatment of the synthetic sample was carried out with $\mathrm{NaOCl} 2 \mathrm{M}$ by overnight for total oxidation of cyanide $\left(18 \mathrm{mg} / \mathrm{L}^{-1}\right)$ to inorganic carbon. The precipitated metal was dissolved with 1.0 mol. $\mathrm{L}^{-1} \mathrm{H}_{2} \mathrm{SO}_{4}$ to yield a final solution with metal concentrations of 200mg.L-1, $14.4 \mathrm{mg} . \mathrm{L}^{-1}$ and $65.5 \mathrm{mg} . \mathrm{L}^{-1}$ of $\mathrm{Cu}^{2+}, \mathrm{Ni}^{2+}$ and $\mathrm{Zn}^{2+}$, respectively. Volumes of $200 \mathrm{~mL}$ were percolated through a column (with $4.0 \mathrm{~g}$ of adsorbent) at flow rate of $2.0 \mathrm{~mL} \mathrm{~min}^{-1}$ and $10 \mathrm{~mL}$ eluted volume was collected at the exit of the bed column to obtain the breakthrough curves given in Fig. $11(a, b)$. It is seen that the column capacity at complete exhaustion reached a plateau when the sample volume was about 70.0 $\mathrm{mL}$ of the effluent. The percentages of saturation of the column, calculated at breakpoint were $73.7,75.2$, and $67.5 \%$ for copper, nickel and zinc respectively.

The adsorption capacities for the metal ions obtained from breakthrough curves are shown in Table 8. It is observed that copper adsorption by cane sugar bagasse is higher than zinc and nickel adsorption (in absence and presence of cyanide). The copper ion interacts strongest with cyanide to form copper-cyanide complexes (anionic) in aqueous solutions on dependency of $\mathrm{pH}$. Therefore, a considerable removal of copper in solution containing cyanide, in acidic conditions, may be due to the formation from insoluble specie $\mathrm{CuCN}$ (Bose et al., 2002). However, the contrast can be observed for zinc and nickel, which form relatively weak complexes with cyanide in aqueous solutions at low $\mathrm{pH}$. Zinc and nickel cyanides complexes are much weaker than copper cyanide complexes, and these metals predominantly exist in the free form (uncomplexed) in presence of cyanide. Thus, a considerable decline in the adsorption of zinc and nickel on the bagasse surface (at $\mathrm{pH} 1.26$ ) could be due to the electrostatic repulsion between the sugarcane bagasse surface (positively charged) and the free zinc and nickel ions (cations).

\begin{tabular}{lcccc}
\hline Synthetic wastewater & $\begin{array}{c}\mathrm{Cu}(\mathrm{II}) \\
\left(200 \mathrm{mg} / \mathrm{L}^{-1}\right)\end{array}$ & $\begin{array}{c}\mathrm{Ni}(\mathrm{II}) \\
\left(14.5 \mathrm{mg} / \mathrm{L}^{-1}\right)\end{array}$ & $\begin{array}{c}\mathrm{Zn}(\mathrm{II}) \\
\left(45.5 \mathrm{mg} / \mathrm{L}^{-1}\right)\end{array}$ & $\begin{array}{c}\mathrm{CN}- \\
\left(18.1 \mathrm{mg} / \mathrm{L}^{-1}\right)\end{array}$ \\
\cline { 2 - 4 } & \multicolumn{3}{c}{$\mathrm{q}(\mathrm{mg}$ metal / g adsorbent $)$} & \\
Initial & 1.85 & 0.145 & 0.421 & - \\
with cyanide & 1.89 & 0.134 & 0.412 & 18.1 \\
After cyanide removal & 2.04 & 0.144 & 0.443 & $\mathrm{ND}$ \\
\hline
\end{tabular}

Table 8. Adsorption capacities of toxic metal ions from simulated electroplating wastewater using sugar cane bagasse. Conditions: $\mathrm{pH} 1.26$; flow: $2.0 \mathrm{~mL} / \mathrm{min}$; mass of the adsorbent: $4.0 \mathrm{~g}$; temperature: $28 \pm 2{ }^{\circ} \mathrm{C}$. 


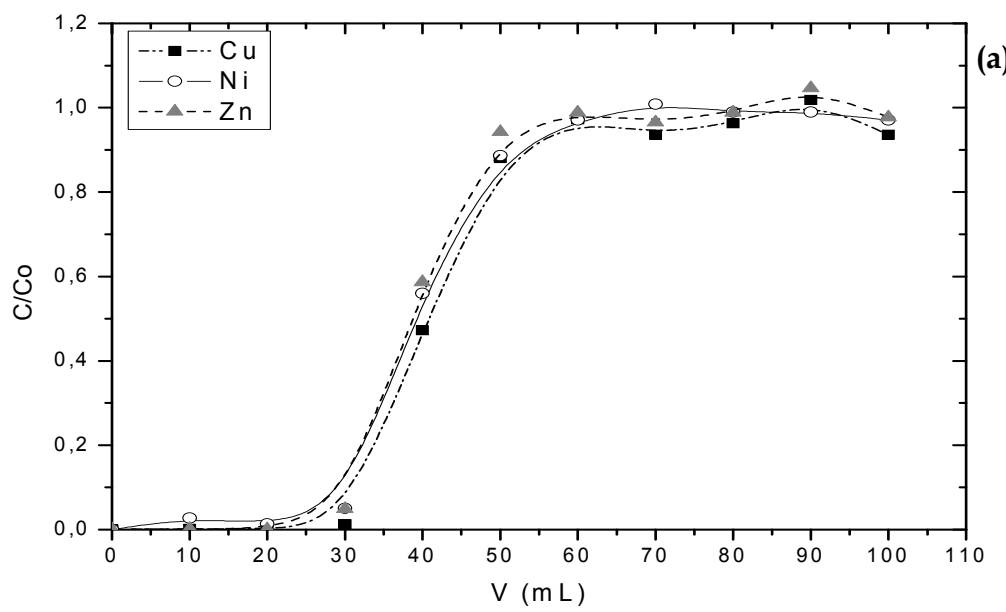

(a)

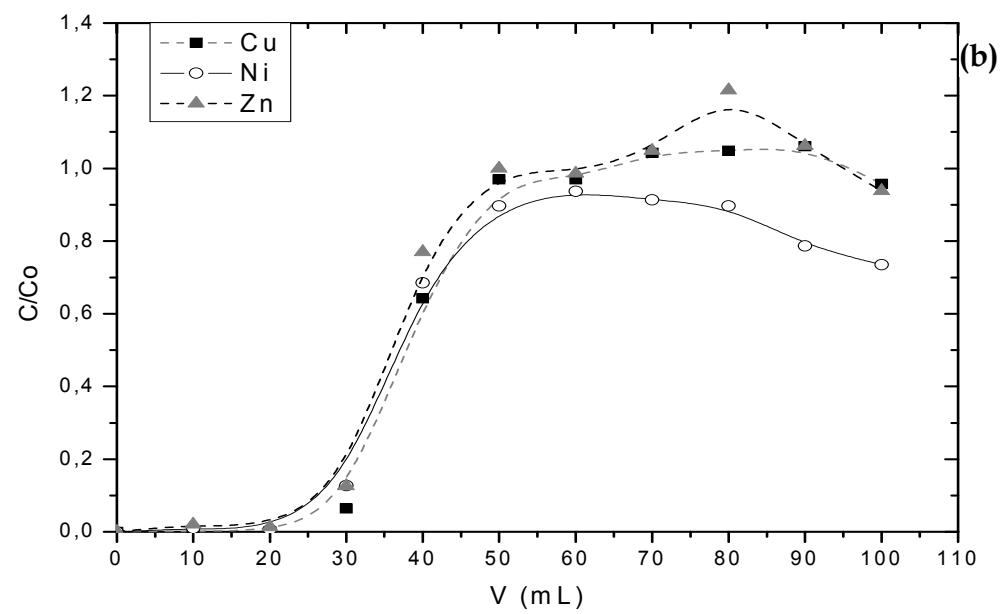

Fig. 11. Breakthrough curves of metals. (a) wastewater with cyanide $(18 \mathrm{mg} / \mathrm{L})$ and (b) wastewater after $\mathrm{NaOCl}$ oxidation of cyanide. Amount of adsorbent $4.0 \mathrm{~g}, \mathrm{Cu}^{+2}$ concentration $200 \mathrm{mg} / \mathrm{L}$ at $\mathrm{pH} 1.78$ and flow rate of $2.0 \mathrm{~mL} / \mathrm{min}$. $C / C_{o}$ represent the ion concentrations for initial and final solution. (Adaptaded from Sousa et al., 2009. Journal Environment Manager, Vol. 90, Nº 11, pp. 3340-3344, ISSN 0301-4797)

\subsubsection{Column application in samples industrial}

Electroplating wastewater contains metal ions, then an effective removal of these species is necessary. For testing the treatability from an wastewater industrial (Juazeiro do Norte Ceara -Brazil) containing $\mathrm{Cu}-\mathrm{Ni}-\mathrm{Zn}$ with sugar cane bagasse, thus $250 \mathrm{~mL}$ wastewater were passed on column in conditions as described previously to obtain the breakthrough. $60 \mathrm{~mL}$ of the final solution for both metals, at $\mathrm{pH} 1.5$, were sufficient to saturate the amount of adsorbent $(4.0 \mathrm{~g})$ on column. Table 9 shows the metals ions removal $(\mathrm{Cu}, \mathrm{Ni}$ and $\mathrm{Zn})$ from an electroplating-wastewater industrial (Juazeiro do Norte - Ceara -Brazil) by sugar cane 
bagasse. For testing the treatability from an wastewater industrial was employed a polyethylene column $(10 \mathrm{~cm} \times 0.8 \mathrm{~cm}$ D.I) packed with $0.30 \mathrm{~g}$ of adsorbent (bed depth of 6 $\mathrm{cm}$ ) at flow rate $1.0 \mathrm{~mL} / \mathrm{min}^{-1}$ at $\mathrm{pH}$ 5. It is observed in Table 9 that the copper removal varied 42.4 to $90.8 \%$ and 13.7 to $52.6 \%$ for nickel from wastewaters.

\begin{tabular}{|c|c|c|c|c|c|c|c|c|c|}
\hline \multicolumn{10}{|c|}{$\begin{array}{c}\text { Wastewater } \\
\text { samples }\end{array}$} \\
\hline Metal ion & Conc. & 1 & 2 & 3 & 4 & 5 & 6 & 7 & 8 \\
\hline \multirow{3}{*}{$\mathrm{Cu}$} & $\mathrm{C}_{\mathrm{o}}\left(\mathrm{mg} \mathrm{L}^{-1}\right)$ & 73.03 & 17.44 & 147.03 & 3.95 & 17.84 & 0.46 & 0.43 & 40.99 \\
\hline & $\mathrm{C}_{\mathrm{e}}\left(\mathrm{mg} \mathrm{L}^{-1}\right)$ & 19.77 & 1.60 & 36.75 & 0.41 & 2.02 & - & 0.099 & 5.39 \\
\hline & Removal,\% & 72.92 & 90.80 & 75.00 & 89.70 & 88.69 & - & 77.35 & 86.84 \\
\hline \multirow{3}{*}{$\mathrm{Ni}$} & $\mathrm{C}_{\mathrm{o}}\left(\mathrm{mg} \mathrm{L}^{-1}\right)$ & 38.45 & 1.15 & 17.94 & 1.52 & 1.62 & 2.28 & 1.58 & 0.82 \\
\hline & $\mathrm{C}_{\mathrm{e}}\left(\mathrm{mg} \mathrm{L}^{-1}\right)$ & 18.98 & 0.77 & 9.09 & 0.77 & 0.91 & 1.34 & 0.75 & - \\
\hline & Removal,\% & 50.64 & 33.21 & 49.33 & 49.62 & 43.96 & 41.14 & 52.59 & - \\
\hline \multirow{3}{*}{$\mathrm{Zn}$} & $\mathrm{C}_{\mathrm{o}}\left(\mathrm{mg} \mathrm{L}^{-1}\right)$ & 40.13 & 10.53 & 31.29 & - & - & - & - & - \\
\hline & $\mathrm{C}_{\mathrm{e}}\left(\mathrm{mg} \mathrm{L}^{-1}\right)$ & 7.15 & 3.34 & 7.26 & - & - & - & - & - \\
\hline & Removal,\% & 82.19 & 68.11 & 76.80 & - & - & - & - & - \\
\hline
\end{tabular}

Table 9. Metals removal from industrial wastewaters collected from galvanic industries (Juazeiro do Norte- Ceara-Brazil). Conditions: Polyethylene column $(10 \mathrm{~cm} \times 0.8 \mathrm{~cm}$ D.I, packed with $0.30 \mathrm{~g}$ adsorbent) in the conditions described in previously

\subsubsection{Column regeneration and metal recovery}

Metal recoveries and the column regeneration were carried out by acid elution method $(\mathrm{HCl}$ $0.1 \mathrm{M}, \mathrm{HNO}_{3} 0.1 \mathrm{M}$ ), under conditions tested for breakthrough curve, with synthetic solution. The results obtained are shown in Fig. $12,30 \mathrm{~mL}$ of acid eluent is efficient for almost complete desorption of the retained metals. Also is noted that the first aliquot of $5 \mathrm{~mL}$ elutes more $70 \%$ of retained ions on column, while the remaining eluant volume $(25 \mathrm{~mL})$ desorbed the rest

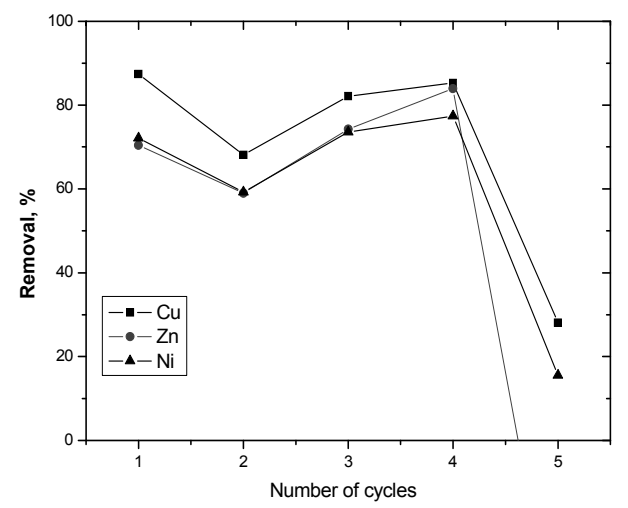

Fig. 12. Removal efficiency with number of cycles for metal ions on cane sugar bagasse from wastewater ((Adaptaded from Sousa et al., 2009. Journal Environment Manager, Vol. 90, $\mathrm{N}^{\circ}$ 11, pp. 3340-3344, ISSN 0301-4797) 
of ions. A test for check the recycling of the adsorbent on column was carried out to passing first water $(30 \mathrm{~mL})$ on column, and $60 \mathrm{~mL}$ of sample solution without treatment, and $\mathrm{HCl} 2 \mathrm{M}$ $(70 \mathrm{~mL})$ to the elution of metals retained, this procedure was repeated 5 times with the same adsorbent of the column. The results shown in Fig.11, indicate that the removal efficiency decreases from $79.6 \%$ to 65 for $(\mathrm{Cu}), 77.4$ to $66.7 \%$ for $(\mathrm{Zn})$ and $73,8 \%$ for $(\mathrm{Ni})$ during their first to fourth cycles. In contrast, a lost drastically of efficiency of the adsorbent was observed after 4 cycles.

\section{References}

Abdel-Halim, E. S., Abou-Okeil, A. \& Hashem, A. (2006). Adsorption of Cr (VI) oxyanions onto modified wood pulp. Polymer - Plastics Technology and Engineering - vol. 45 No 1,pp. 71-76, ISSN 1525-6111

Abou-Elela, S. I., Ibrahim, H. S. , Abou-Taleb, E. (2008). Heavy metal removal and cyanide destruction in the metal plating industry: an integrated approach from Egypt. Environmentalist vol. 28 No 3,pp. 223-229, ISSN 1573-2991

Agrawal, A., Sahu, K.K. (2009). An overview of the recovery of acid from spent acidic solutions from steel and electroplating industries, Journal of Hazardous Materials Vol. 171,No 1-3, pp.61-75

Akcil, A. (2003). Destruction of cyanide in gold mill effluents: biological versus chemical treatments. Biotechnology Advances, Volume 21, No 6,pp. 501-511, ISSN 0734-9750

Akcil, A. (2003). Destruction of cyanide in gold mill effluents: biological versus chemical treatments, Biotechnology Advances, Vol. 21, No 6, pp. 501-511, ISSN 0734-9750

Aksu, Z., Acikel, U., Kabasakal, E., Treser, S. (2002) Equilibrium modelling of individual and simultaneous biosorption of chromium(VI) and nickel(II) onto dried activated sludge, Water Research Vol. 36 No 12 (2002) 3063-3073

Alonso-González, O.;Nava-Alonso, F., Uribe-Salas, A., Dreisinger, D. (2010) Use of quaternary ammonium salts to remove copper-cyanide complexes by solvent extraction, Minerals Engineering, Vol. 23, № 10, pp. 765-770, ISSN 0892-6875

Amarasinghe,B.M.W.P.K. Williams, R.A. (2007).Tea waste as a low cost adsorbent for the removal of $\mathrm{Cu}$ and $\mathrm{Pb}$ from wastewater, Chemical Engineering Journal, Vol.132, No 1-3, pp. 299-309, ISSN 1385-8947.

Amuda, O. S., Giwa, A.A., Bello, I.A.(2007). Removal of heavy metal from industrial wastewater using modified activated coconut shell carbon Biochemical Engineering Journal 2007; Vol. 36 No 2,pp. 174-181, ISSN 1369-703X

Atkinson, BW., Bux F, Kasan HC. 1998. Considerations for application of biosorption technology to remediate metal-contaminated industrial effluents. Water AS. Vol. 24, No 2, pp. 129-135. ISSN: 0378-4738

Ayranci, E., Hoda, N.(2005).Adsorption kinetics and isotherms of pesticides onto activated carbon-cloth,Chemosphere Vol. 60, No11, pp. 1600-1607, ISSN 0045-6535 60 (2005) 1600-1607.

Babel, S., Kurniawan, A. (2003). Low-cost adsorbents for heavy metal uptake from contaminated water: a review. Journal of Hazardous Materials, Vol. 97, No 1-3, pp. 219-243, ISSN 0304-3894

Barakat, M.A, Chen, Y.T, Huang, C.P.(2004). Removal of toxic cyanide and Cu(II) Ions from water by illuminated TiO2 catalyst, Applied Catalysis B: Environmental, Vol. 53, No 1, pp. 13-20, ISSN 0926-3373. 
Barreto, A.C.H.; Costa, M.M.; Sombra, A.S.B.; Rosa, D.S.; Nascimento, R.F.; Mazzetto, S.E. \& P. B. A. Fechine. (2010). Chemically Modified Banana Fiber: Structure, Dielectrical Properties and Biodegradability. Journal of Polymers and the Environment, Vol. 18, pp 523-531, ISSN 1572-8900

Barreto, A.C.H.; Esmeraldo M.A.; Rosa D.S.; Fechine P.B.A \& Mazzetto S.E. (2010). Cardanol biocomposites reinforced with jute fiber: microstructure, biodegradability and mechanical properties, Polymer Composites, Vol. 31, $\mathrm{N}^{\circ} 11$, pp. 1928-37, ISSN 0272-8397

Barreto, A.C.H.; Rosa, D. S.; Fechine, P. B. A. \& Mazzetto, S .E. (2011). Properties of sisal fibers treated by alkali solution and their application into cardanol-based biocomposites. Composites: Part A, Vol. 42, pp. 492-500, ISSN 1359-835X

Behnamfard, A., Salarirad, M.M. (2009). Equilibrium and kinetic studies on free cyanide adsorption from aqueous solution by activated carbon, Journal of Hazardous Materials, Vol. 170, No 1, pp. 127-133, ISSN 0304-3894

Bilba, K. \& Ouensanga, A. (1996). Fourier transform infrared spectroscopic study of thermal degradation of sugar cane bagasse. Journal of an analytical And Applied Pyrolysis. Vol. 38, pp. 61-73, ISSN 0165-2370

Bose, P., Bose, MA., Kumar, S. (2002). Critical evaluation of treatment strategies involving adsorption and chelation for waster containing copper, zinc and cyanide. Advances in Environmental Research, Vol. 7, No 1, pp. 179-195, ISSN 1093-0191

Botz, M., Devuyst, E, Mudder, T, Norcross,R., Ou, B.,. Richins, R ,et al. (1995), Cyanide: an overview of cyanide treatment and recovery methods. Mining Environmental Management, Vol. 3, No 2. pp. 4-16. ISSN: 0969-4218

Bower, D.I. \& Maddams, W.F. (2006). The vibrational spectroscopy of polymers, Cambridge University Press, ISBN 0521421950, New York.

Brower, J.B., Ryan, R.L. ,Pazirandeh, M. (1997). Comparison of ion-exchange resins and biosorbents for the removal of heavy metals from plating factory wastewater, Environmental Science and Technology Vol. 31,No 10, pp. 2910-2914. ISSN, 1520-5851

Brundle, R.; Evans Jr., C.A. \& Wilson S. (1992). Encyclopedia of materials characterization: surfaces, interfaces, thin films, Buttertworth-Heinemann, ISBN 0750691689, London.

Buckeridge, M.S. \& Goldman, G.H. (2011) Routes to Cellulosic Ethanol, Springer, ISBN 0387927395, New York.

Butter, TJ., Evison, L.M Hancock, I.C. , Holland, F.S., Matis, K.A., Philipson, A.,. Sheikh, A.I., Zouboulis, A.I. (1998). The removal and recovery of cadmium from dilute aqueous solutions by biosorption and electrolysis at laboratory scale. Water Research. Vol. 32,No 2 ,pp. 400-406 ISSN 0043-1354

Calado V.; Barreto D.W. \& D’Almeida, J.R.M. (2000). The Effect of a Chemical Treatment on the Structure and Morphology of Coir Fibers. Journal of Materials Science Letters, Vol. 19, N²3, pp. 2151-2153, ISSN 0261-8028

Cay, S., Uyanik, A., Ozasik, A.(2004) Single and binary component adsorption of copper(II) and cadmium(II) from aqueous solutions using tea-industry waste, Separation and Purification Technology, Vol. 38, No 3,pp. 273-280, ISSN 1383-5866

Chang, M.M.; Chou, T.C. \& Tsao, G.T. (1981). Structure, Pretreatment and Hydrolysis of Cellulose, In: Advances in Biochemical Engineering/Biotechnology. pp.15-42. Spinger, ISBN 3-540-11018-6, New York. 
Clesceri, L.S., A.E. Greenberg, and A.D.Eaton, (Editors). (1998). Standard Methods for the Examination of Water and Wastewater. 20th Edition. ISBN: 0875532357. American Public Health Association. Washington, D.C. 1325 p.

Cooney, D.O.(1999). Adsorption design for wastewater treatment, Lewis publishers, ISBN 1566703336 9781566703338. Boca Raton, Fl

Crini, G. (2005). Recent developments in polysaccharide-based materials used as adsorbent in wastewater treatment. Progress in Polymer Science. Vol.30, No 1, 38-70, ISSN 00796700 .

Crini, G. (2006). Non-conventional low-cost adsorbents for dye removal: a review. Bioresource Technology Vol. 97,No 9,pp. 1061-1085,. , ISSN 0960-8524

Crisafully, R.; Milhome, M.A; Cavalcante, R.M., Silveira, E.R; Nascimento, R.F. (2005) Adsorption of PAHs from petrochemical plant wastewater using low cost adsorbents. Separation and purification Technology, Vol. 99, No 10, pp. 4515-4519, ISSN 0960-8524

Dąbrowski, D., (2001) Adsorption - from theory to practice, Advances in Colloid and Interface Science, Vol. 93, No 1-3,pp. 135-224, ISSN 0001-868

Dash, R., Balomajumder, C. \& Kumar, A. (2008). Removal of cyanide from water and wastewater using granular activated carbon. Chemical Engineering Journal, Vol 146, No 3, pp. 408-413, ISSN 1385-8947

Deosarkar S.P, Pangarkar V. G. Adsorptive separation and recovery of organics from PHBA and SA plant effluents.(2004),Separation and Purification Technology, Vol. 38, No 3, pp. 241-254, ISSN 1383-5866

Duncan, J.R., Brady,D., Stoll, A. (1994). Biosorption of Heavy Metals Cations by Non-Viable Yeast Biomass Environmental Technology, Vol.15 No 5 pp. 429-438,ISSN: 1479-487X

Dutra, A. J. B., Rocha, G. P. \& Pombo, F. R. (2008). Copper recovery and cyanide oxidation by electrowinning from a spent copper-cyanide electroplating electrolyte. Journal of Hazardous materials Vol.. 152, No 21, pp. 648-655, ISSN 0304-3894

Ebbs, S. (2004). Biological degradation of cyanide compounds, Current Opinion in Biotechnology Vol.15,No 3 pp. 231-236 ISSN 0958-1669.

Esmeraldo, M.A. (2006). Preparação de Novos Compósitos Suportados em Matriz de Fibra Vegetal, Master's Degree, Departamento de Química Orgânica e Inorgânica, Universidade Federal do Ceará, Fortaleza-CE-Brazil.

Esmeraldo, M.A.; Barreto, A.C.H.; Freitas, J.E.B.; Fechine, P.B.A.; Sombra, A.S.B.; Corradini, E.; Mele, G.; Maffezzoli, A. \& Mazzetto, S.E. (2010). Dwarf-green coconut fibers: a versatile natural renewable raw bioresource. Treatment morphology and physicochemical properties. Bioresources, Vol. 5, N 4, pp. 2478-2501, ISSN 1930-2126

Febrianto, J., Kosasih, A.N., Sunarso, J., Ju, Y-H., Indraswati, N., Ismadji, S. (2009) Equilibrium and kinetic studies in adsorption of heavy metals using biosorbent: A summary of recent studies, Journal of Hazardous Materials, Vol. 162, No 2-3, , pp. 616-645, ISSN 0304-3894.

Fernando, K., Lucien, F., Tran T., Carter, M. (2008). Ion exchange resins for the treatment of cyanidation tailings. Part 3 . Resin deterioration under oxidative acid conditions. Minerals Engineering. Vol. 21, No 10,pp. 683-690, ISSN 0892-6875

Franson MH. (1992). Standard methods for the examination of water and wastewater. In: Franson, editor, 18th ed. Washington, DC: American Public Health Association, American Water Works Association, Water Environment Federation. 
Freeman, H.M. (1989). Standard Handbook of Hazardous Waste Treatment and Disposal,(Ed.) McGraw-Hill, New York, New York, NY, ISBN 0-07022042-5.

Freundlich, H.M.F. (1906). Uber die adsorption in lösungen, Zeitschrift für Physikalische Chemie - 470, vol.57(A), pp 385 ISSN 0942-9352

Georgopoulos, S.T.; Tarantili, P.A.; Avgerinos E.; Andreopoulos A.G. \& Koukios, E.G. (2005). Thermoplastic polymers reinforced with fibrous agricultural residues. Polymer Degradation and Stability, Vol. 90, pp. 303-312, ISSN 0141-3910

Gijzen, H.J. (2000). Cyanide toxicity and cyanide degradation in anaerobic wastewater treatment. Water Research Vol. 34,No 9, pp. 2447, ISSN 0043-1354

Gilbert, R.D. (1994). Cellulosic polymers, blends and composites, 115-130. Hanser Publishers, ISBN 3-446-16521-5, New York.

Guo, X., Zhang, S. \& Shan, X. (2008). Asorption of metal ions on lignin. Journal of Hazardous Materials Vol., Vol. 151,No 1,pp. 134-142, ISSN 0304-3894

Gupta, B. S., Curran A, M., Hasan, S. \& Ghosh, T. K. (2009). Adsorption characteristics of Cu and $\mathrm{Ni}$ on Irish peat moss. Journal of Environmental Management Vol.90,No 2,pp. 954-960, , ISSN 0301-4797

Gupta, V.K., Srivastava, S.K. Mohan, D., Sharma, S. (1997). Design parameters for fixed bed reactors of activated carbon developed from fertilizer waste for the removal of some heavy metal ions, Waste Management, Vol 17, No 8, 1997, pp. 517-522, ISSN 0956-053X.

Han, B., Shen, Z., Wickramasinghe, S. (2005). Cyanide removal from industrial wastewaters using gas membranes. Journal of Membrane Science Vol. 257, No 1-2, pp. 171-181, ISSN 0376-7388

Han, S. O. \& Choi, H. Y. (2010). Morphology and surface properties of natural fiber treated with electron beam, Microscopy: Science, Technology, Applications and Education, Vol. 3, ISBN 978-84-614-6191-2, pp. 1880-1887

Hashem, A. (2006). Amidoximated sunflower stalks (ASFS) as a new adsorbent for removal of $\mathrm{Cu}$ (II) from aqueous solution. Polymer - Plastics Technology and Engineering 45, No 1,pp. 35-42, ISSN 1525-6111

Hashem, A., Abdel-Halim, E.S., El-Tahlawy, K H. F. \& Hebeish, A. (2005). Enhancement of adsorption of $\mathrm{Co}$ (II) and Ni (II) ions onto peanut hulls though esterification using citric acid. Adsorption Science and Technology Vol.23, No 5 pp. 367-380, ISSN- 02636174

Hashem, A., Abou-Okeil, A., El-Shafie, A. \& El-Sakhawy, M. (2006). Grafting of high acellulose pulp extracted from sunflower stalks for removal of $\mathrm{Hg}$ (II) from aqueous solution. Polymer - Plastics Technology and Engineering Vol.45,No 1 pp. 135-141 ISSN 1525-6111

Hashem, A., Akasha, R.A., Ghith A., Hussein, D.A. (2007). Adsorbent based on agricultural wastes for heavy metal and dye removal: a review. Energy Education Science and Technology. Vol.19, pp. 69-86 ISSN 1301-8361

Hashem, A., Aly, A. A. \& Aly, A. S. (2006). Preparation and utilization of cationized sawdust. Plastics Technology and Engineering Vol. 45, No. 3,pp. 395-401, ISSN 15256111

Hashem, A., Aly, A. A., Aly, A. S. \& Hebeish, A. (2006). Quaternization of cotton stalks and palm tree particles for removal of acid dye from aqueous solutions. Plastics Technology and Engineering Vol.45,No 3, pp. 389-394, ISSN 1525-6111 
Hashem, A., Elhammali M. M., Hussein, A. H. \& Senousi, M. A. (2006). Utilization of sawdust-based materials as adsorbent for wastewater treatment. Plastics Technology and Engineering.Vol. 45,No 7, pp. 821-827, , ISSN 1525-6111

Hashem, A., Elhmmali, M. M., Ghith, A., Saad, E.E. \& Khouda, M. M. (2007). Utilization of chemically modified Alhagi residues for the removal of $\mathrm{Pb}$ (II) from aqueous solution. Energy Education Science and Technology 20, pp. 1-19, ISSN 1301-8361

Hayashi, A. M. (2001). Remoção de Cromo Hexavalente através de Processo de Biossorção em Algas Marinhas. Tese de Doutorado da Faculdade de Engenharia Química, Unicamp, Campinas, SP, p 20, 22, 61, 62 -63, 80, 82 -83, 86

Ho, YS, McKay, G. The kinetics of sorption of basic dyes from aqueous solutions by sphagnum moss peat(1998). Canadian Journal of Chemical Engineering,Vol.76, No 4,pp. 822-827. ISSN 1939-019X

Igwe, J.C., Abia, A.A. (2007). Adsorption kinetics and intraparticulate diffusivities for bioremediation of $\mathrm{Co}(\mathrm{II}), \mathrm{Fe}(\mathrm{II})$ and $\mathrm{Cu}(\mathrm{II})$ ions from waste water using modified and unmodified maize cob. International Journal of the Physical Sciences, vol. 2 , pp. 119-127. ISSN 1992-1950

Ismail, I., Abdel-Monem, N.; Fateen, S-E., Abdelazeem, W. (2009). Treatment of a synthetic solution of galvanization effluent via the conversion of sodium cyanide into an insoluble safe complex, Journal of Hazardous Materials, Vol. 166, No 2-3, pp. 978983, ISSN 0304-3894

Isom, G.E., Borowitz, J.L. (1995). Modification of cyanide toxicodynamics : mechanistic based antidote development, Toxicology Letters Vol.82-83,pp.795-799, ISSN 03784274

Jnr, M.H., Spiff, A. I. (2005). Effects of temperature on the sorption of $\mathrm{Pb} 2+$ and $\mathrm{Cd} 2+$ from aqueous solution by Caladium bicolor (Wild Cocoyam) biomass, Electronic Journal of Biotechnology Vol. 8, No 2,162-169. ISSN 0717-3458

Joint Committee on Powder Diffraction Standards (JCPDS) - International Center for Diffraction Data. (1986). JCPDS File 50-2241.

Kavitha, D.,Namasivayam, C. Experimental and kinetic studies on methylene blue adsorption by coir pith carbon, (2007). Bioresource Technology, Vol. 98, No 1, pp. 1421, ISSN 0960-8524

Klenk, H., Griffiths, A., Huthmacher, K., Itzel, H., Knorre,H., Voight, C., et al. (1996). Cyano, inorganics, in: Ullmanns encyclopedia of industrial chemistry, A8 ,in: W Gerhartz, YS Yamamoto, L Kaudy, R Pfefferkorn, JF Rounsaville, Editors VCH, pp. 159-190. ISBN 978-3527303854

Kumar, M.N.V.R. (2000). A review of chitin and chitosan applications. Reactive and Functional Polymers Vol.46: No 1, pp. 1-27, ISSN 1381-5148

Kumar, U., Bandyopadhyay, M. (2006). Sorption of cadmium from aqueous solution using pretreated rice husk, Bioresource Technology, Vo. 97, No 1,pp. 104-109, ISSN 09608524

Kundu, S. Gupta, A.K. (2005). Analysis and modeling of fixed bed column operations on $\mathrm{As}(\mathrm{V})$ removal by adsorption onto iron oxide-coated cement (IOCC), Journal of Colloid and Interface Science, Vol. 290, No 1, pp. 52-60. ISSN: 0021-9797

Kurama, H.,Çatalsarik, T. (2000). Removal of zinc cyanide from a leach solution by an anionic ion-exchange resin, Desalination, Vol. 129, No 1,pp. 1-6, ISSN 0011-9164 
Lagergren, S. Zur theorie der sogenannten adsorption geloester stoffe,Veternskapsakad Handlingar 24 (1898) 1-39.

Langmuir, I. (1918).The adsorption of gases on plane surfaces of glass, mica and platinum. Journal of the American Chemical Society, Vol 40, No 9, pp 1361-1403, ISSN: 00027863

Lanza, M. \& Bertazzoli R. (2002). Cyanide oxidation from wastewater in a flow electrochemical reactor. Industrial and Engineering Chemistry Research Vol. 41 No 1, pp. 22-26, ISSN 1520-5045

Liu, F.; Wu, J.; Chen, K. \& Xue, D. (2010). Morphology Study by Using Scanning Electron Microscopy, Microscopy: Science, Technology, Applications and Education, Vol. 3, ISBN 978-84-614-6191-2, pp. 1781-1792.

López, R.; Gutarra, A.(2000). Descoloração de águas residuais da indústria têxtil. Química Têxtil, vol. 59, pp. 66-69, ISSN 0102-8235.

Low, K.L, Lee,C.K, Mak,S.M. (2004). Sorption of copper and lead by citric acid modified Wood, Wood Science and Technology Vol.38, No 8, pp.629-640, ISSN 1432-5225

Low, K.S., Lee, C.K. (1991). Cadmium update by moss colympers delesertic, besch, Bioresource Technology Vol. 38, No 1 ,pp.1-6. ISSN 0960-8524

Lu, J., Dreisinger, D.B. and Cooper, W.C. (2002). Thermodynamics of the aqueous coppercyanidesystem. Hydrometallurgy, Vol. 66,No 1-3, pp. 23-36, ISSN 0304-386X

Luo, F., Liu, Y.,Li, X., Xuan ,Z. , Ma, J. (2006). Biosorption of lead ion by chemically-modified biomass of marine brown algae Laminaria japonica. Chemosphere Vol. 64, No 7,pp. 1122-1127, ISSN 0045-6535

Mattuschka, B., Straube, G., J (1993) Journal of Chemical Technology and Biotechnology,Vol. 58,No 2,pp. 157-63. ISSN: 1097-4660

McKay, G. (1996) (Editors), Design of adsorption contatacting systems,in: Use of Adsorbents for the Rremoval of Pollutans from Wasterwaters,pp 99-131,CRC press,Inc, Boca Raton, Florida ISBN: 0-8493-6920-7

Mohan, D.; Singh, K. P., (2002) Single- and multi-component adsorption of cadmium and zinc using activated carbon derived from bagasse-an agricultural waste, Water Research,Vol. 36, No 9,pp. 2304-2318, ISSN 0043-1354

Monser L. \& Adhoum, N. (2002). Modified activated carbon for the removal of copper, zinc, chromium and cyanide from wastewater. Separation and Purification Technology. Vol. 26,No 2-3, pp. 137-146, ISSN 1383-5866.

Monteagudo, J., Rodríguez, L. ,Villaseñor, J. (2004). Advanced oxidation processes for destruction of cyanide from thermoelectric power station waste waters. Journal of Chemical Technology and Biotechnology. Vol. 79 No 2, (June 2011) pp. 117-125, 10974660 ISSN 1097-4660

Morán, J.I.; Alvarez, V.A.; Cyras, V. \& Vázquez, A. (2008). Extraction of cellulose and preparation of nanocellulose from sisal fibers. Cellulose, Vol. 15, pp. 149-159, ISSN0969-0239

Moreira, S. A., Sousa, F. W., Oliveira, A. G., Brito, E.S, and Nascimento, R. F. (2009). "Metal removal from aqueous solution using cashew bagasse, Química Nova vol. 32, No 7, pp.1717-1722. ISSN 0100-4042.

Morgan, S.M. \& Lee,C.M. (1997). Metal and acid recovery options for the plating industry, Resources, Conservation and Recycling Vol.19,No 1, pp. 55-71, ISSN: 09213449 
Moussavi, G., Talebi, S. (2011). Comparing the efficacy of a novel waste-based adsorbent with PAC for the simultaneous removal of chromium (VI) and cyanide from electroplating wastewater, Chemical Engineering Research and Design, ISSN 02638762, doi.10.1016/j.cherd.2011.10.014.(in press)

Moussavi,, G.; Khosravi, R. (2010). Removal of cyanide from wastewater by adsorption onto pistachio hull wastes: Parametric experiments, kinetics and equilibrium analysis, Journal of Hazardous Materials, Volume 183, No 1-3, 15,pp 724-730, ISSN 03043894 ,

Mudder, T. \& Botz, M. (2004). Cyanide and society: a critical review. European Journal of Mineral Processing and Environmental Protection Vol.4, No 1, pp. 62-74, ISSN 13030868.

Nagarale, R.K., Gohil, G.S.,. Shahi, V. K. (2006). Recent developments on ion-exchange membranes and electro-membrane processes, Advances in Colloid and Interface Science Vol. 119, No 2-3 97-130, ISSN 0001-8686

Naja, G., Murphy, V. \& Volesky, B. (2010). Biosorption, Metals, In Encyclopedia of Industrial Biotechnology: Bioprocess, Bioseparation, and Cell Technology.pp. 1-29. John Wiley \& Sons, DOI: 10.1002/9780470054581.eib166

Neto, V. O. S., Oliveira, A. G., Teixeira, R. N. P., Silva, M. A. A., Freire, P. T. C., Keukeleire, D. D., Nascimento, R. F. (2011). Use of coconut bagasse as alternative adsorbent for separation of copper(II) ions from aqueous solutions: Isotherms, kinetics, and thermodynamic studies, BioResources Vol. 6 , No3,pp. 3376-3395. ISSN: 1930-2126

Ngah, W. S. W., Teong, L. C. \& Hanafiah, M. A. K. M. (2011). Adsorption of dyes and heavy metal ions by chitosan composites: A review. Carbohydrate Polymers Vol.83, No 4-1, pp. 1446-1456, ISSN 0144-8617

Ngah, W.S. W., Hanafiah, M.A.K.M. (2008). Adsorption of copper on rubber (Hevea brasiliensis) leaf powder: Kinetic, equilibrium and thermodynamic studies, Biochemical Engineering Journal, Vol. 39, № 3, pp. 521-530, ISSN 1369-703X.

Noeline, B.F; Manohar, D.M.; Anirudhan, T.S. (2005). Kinetic and equilibrium modelling of lead(II) sorption from water and wastewater by polymerized banana stem in a batch reactor, Separation and Purification Technology, Vol. 45, No 2, pp.131-140, ISSN 1383-5866

Ouajai, S. \& Shanks, R,A, (2005). Composition, structure and thermal degradation of hemp cellulose after chemical treatments. Polymer Degradation and Stability. Vol. 89, pp. 327-335, ISSN 0141-3910

Pagnanelli, F., Mainelli, S., Veglio, F. \& Toro, L. (2003). Heavy metal removal by olive pomace: biosorbent characterization and equilibrium modeling. Chemical Engineering Science Vol. 58, No pp. 4709-4717, ISSN 0009-2509

Park, D., Kim, Y., Lee, D. \& Park, J. (2008). Chemical treatment for treating cyanidescontaining effluent from biological cokes wastewater treatment process. Chemical Engineering Journal Vol.143, No 1-3, pp. 141-146, ISSN 1385-8947

Pasavant, P., Apiratikul, R., Sungkhum, V., Suthiparinyanony, P., Wattanachira, S., Marhaba, T. F., (2006) Biosorption of $\mathrm{Cu} 2+, \mathrm{Cd} 2+, \mathrm{Pb} 2+$, and $\mathrm{Zn} 2+$ using dried marine green macroalga Caulerpa lentillifera Bioresource Technology Vol.97 , No 18 pp. 2321-2329. , ISSN 0960-852 
Patil, Y.B, Paknikar, K.M. (2000). Development of a process for biodetoxification of metal cyanides from wastewater, Process Biochem. Vol.35, No 10, pp. 1139-1151, ISSN 1359-5113

Patil, YB., Paknikar, KM. 1999. Removal and recovery of metal cyanides using a combination of biosorption and biodegradation processes. Biotechnology Letters, Vol. 21, No 10,pp.913-919. ISSN: 1573-6776

Qiu, T. S., Cheng, X. X., Hao, Z. W. \& Lou, X. P. (2002). Present situation and development for wastewater containing cadmium treatment technology. [J]. Sichuan Nonferrous Metals, No 4: pp. 38-41 ISSN 1006-4079

Regel-Rosocka, M. (2010). A review on methods of regeneration of spent pickling solutions from steel processing, Journal of Hazardous Materials Vol. 177, No 1-3, 57-69, ISSN 0304-3894

Saarela, K., Kuokkanen, T., Peramaki, P. \& Valimaki, I. (2005). Analyses and treatment methods of waste water containing metal cyanides. Journal of Solid Waste Technology and Management vol. 31, No 1, pp. 38-45, ISSN: 1088-1697

Saikaew, W., Kaewsarn,P., Saikaew, W. (2009). Pomelo Peel: agricultural waste for biosorption of cadmium ions from aqueous solutions, World Academy of Science, Engineering and Technology. Vol.56, pp.287-291. INSS 56 287-291

Sankararamakrishnan, N. , Sharma,A.K., Sanghi,R., Novel chitosan derivative for the removal of cadmium in the presence of cyanide from electroplating wastewater(2007), Journal of Hazardous Materials, Vol. 148, No 1-2, ,pp. 353-359, ISSN 0304-3894

Sekhar, K. C.; Kamala, C. T.; Chary, N. S.; Anjaneyulu, Y., Inter. J. Min. Processing, 68(2003)

Şengil, İ.A., Özacar, M., Türkmenler, H. (2009). Kinetic and isotherm studies of $\mathrm{Cu}(\mathrm{II})$ biosorption onto valonia tannin resin, Journal of Hazardous Materials, Vol. 162, No 23,pp. 1046-1052, ISSN 0304-3894

Seung-Mok, Lee; Diwakar, Tiwari. (2009). Application of ferrate(VI) in the treatment of industrial wastes containing metal-complexed cyanides: A green treatment, Journal of Environmental Sciences, V. 21, No 10, pp 1347-1352, ISSN 1001-0742,

Shen, J. \& Duvnjak, Z. (2005). Adsorption kinetics of cupric and cadmium ions on corncob particles. Process Biochemistry Vol. 40,No 11, pp. 3446-3454, ISSN 1359-5113

Shibi, I.G; Anirudhan T.S. (2005). Adsorption of Co(II) by a carboxylate-functionalized polyacrylamide grafted lignocellulosics, Chemosphere vol. 58, No 8,pp. 1117-1126, ISSN 0045-6535

Silva, R.M.P., Rodríguez,A. B., De Oca, J.M.G., Moreno, D.C. (2009). Biosorption of chromium, copper, manganese and zinc by Pseudomonas aeruginosa AT18 isolated from a site contaminated with petroleum. Bioresource Technology, Vol. 100,No 4, pp. 1533-1538, ISSN 0960-8524

Singh, K., Mohan, S. (2004). Kinetic studies of the sucrose adsorption onto an alumina interface, Applied Surface Science, Vol 221, No 1-4, pp. 308-318, ISSN 0169-4332.

Smith, A., Mudder, T. (1991). The Chemistry and Treatment of Cyanidation Wastes,(2th Edition), Mining Journal Books Limited, pp. 327-333, ISBN: 0900117168, London

Solomonson, L.P. (1981). Cyanide as a metabolic inhibitor. In: Cyanide in Biology , B. Vennesland, E.E. Conn, C.J. Knowles, J. Westley and F. Wissing, Editors, pp. 385314, Academic Press, 0127169806, London. 
Sousa, F. W. (2007). Adsorção de metais tóxicos em efluente aquoso usando pó da casca de coco verde tratado. Dissertação de Mestrado, Universidade Federal do Ceará. Departamento de Engenharia Hidráulica e Ambiental, Fortaleza, Ceará, Brasil

Sousa, F. W., Moreira, S. A., Oliveira, A. G., Cavalcante, R. M., Rosa, M. F, and Nascimento, R. F. (2007). The use of green coconut shells as absorbents in the toxic metals, Química. Nova. vol.30, n.5, pp. 1153-1157. ISSN 0100-4042.

Sousa, F. W.,Oliveira, A.G., Ribeiro, J.P., De Keukeleire, Denis., Sousa, A.F., Nascimento, R.F. (2011).Single and multielementary isotherms of toxic metals in aqueous solution using treated coconut shell powder. Desalination and Water Treatment, Vol. 36, pp. 289-296, ISSN 1944-3994

Sousa, F. W.;Oliveira, A. G. ; Ribeiro, J. P.; Keukeleire, D.; Nascimento, R.F.; Rosa, M. F. (2010). Green coconut shells applied as adsorbent for removal of toxic metal ions using fixed-bed column technology. Journal of Environmental Management, vol. 91, pp. 1634-1640. ISSN 0301-4797

Sousa, F.W.; Sousa, M.J.; Oliveira, I.R.N.; Oliveira, A.G.; Cavalcante, R.M.; Fechine, P.B.A.; Neto, V.O.S.; Keukeleire, D. \& Nascimento, R. F. (2009). Evaluation of a low-cost adsorbent for removal of toxic metal ions from wastewater of an electroplating factory. Journal Environment Manager, Vol. 90, N 11, pp. 3340-3344, ISSN 03014797

Stuart, B.H. (2004). Infrared Spectroscopy: Fundamentals and Applications. ANTS - John Wiley \& Sons, ISBN 978-0-470-85428-0, San Francisco.

Szpyrkowicz, L.; Kaul, S.N; Molga, E.; DeFaveri, E.; (2000). Comparison of the performance of a reactor equipped with a Ti/Pt and an SS anode for simultaneous cyanide removal and copper recovery, Electrochimica Acta, Vol. 46, № 2-3, pp 381-387, ISSN 0013-4686,

Torma, A.E. e Apel, W.A. (1991). Recovery of Metals from Dilute Effluent Streams by Biosorption Methods. In: R.G. Reddy, W.P. Imrie e P.B. Queneau (Eds.,Residues and Effluents - Processing and Environmental Consideration. TMS, p.735

Ulbricht, M. (2006). Advanced functional polymer membranes, Polymer Vol. 47 No 7, pp. 2217-2262. ISSN 0032-3861.

Vargas, T., Jerez, C.A., Wierts, J.V.,Toledo, H.(Eds). (1995). Biohydrometallurgical Processing: Vol. I: Microbiology and Dissolution Mechanisms in Bioleaching: Bioleaching Processes for Gold, Copper and Non-Sulfide Ores, Universidad de Chile, Viña del Mar, ISBN: 95619-0209-5.

Vázquez, G.; Álvarez, J. G.; Freire, S.; Lorenzo, M. L.; Antorrena, G., (2002) Removal of cadmium and mercury ions from aqueous solution by sorption on treated Pinus pinaster bark: kinetics and isotherms, Bioresource Technology, Vol. 82, No 3, pp. 247251, ISSN 0960-8524

Viera, R.G.P.; Filho, G. R.; de Assunção, R.M.N.; Meireles, C. S.; Vieira, J. G. \& Oliveira, G. S. (2007). Synthesis and characterization of methylcellulose from sugar cane bagasse cellulose. Carbohydrate Polymers, Vol. 67, pp. 182-189, ISSN 0144-8617

Vijayaraghavan, K., Yun, Y-S. (2008). Bacterial biosorbents and biosorption, Biotechnology Advances, Vol. 26, No 3,pp. 266-291, ISSN 0734-9750

Vilar, V.J.P. , Botelho, C.M.S., Boaventura, R.A.R. (2007). Chromium and zinc uptake by algae Gelidium and agar extraction algal waste: Kinetics and equilibrium. Journal of Hazardous Materials Vol. 149, No 3 643-649, ISSN 0304-3894. 
Volesky, B.(Ed.). (1990). Biossorption of Heavy Metals.: CRC Press, Inc., ISBN-10: 0849349176, Boston, USA

Waalkes, M.P. (2000),Cadmium carcinogenesis in review. Journal of Inorganic Biochemistry. Vol. 79 No 1-4,pp. 241-244, ISSN 0162-0134

Wang, P., Min, X. B. \& Chai, L. Y. (2006). The status of treatment technology on wastewater containing cadmium and the development of its bio-treatment technology. [J]. Industrial Safety and Dust Control,, Vol. 32, No 8,pp. 14-16 ISSN- 1001-425X

Watanabe, M., Kawahara,K., Sasaki, K. \& Noparatnaraporn, N. (2003). Biosorption of cadmium ions using a photosynthetic bacterium, Rhodobacter sphaeroides $\mathrm{S}$ and a marine photosynthetic bacterium, Rhodovulum sp. and their biosorption kinetics. Journal of Bioscience and Bioengineering 95, pp.374-378 ISSN 1347-4421

Weber, W.J \& Morris, J.C. (1963). Kinetics of adsorption on carbon from solution (1963), Journal Sanitary Engineering Division. Proceedings American Society of Civil Engineers. Vol. 89 pp.31-59. ISBN/ISSN: 0044-7986.

White, C. , Wilkinson, S.C., Gadd, G.M. (1995). The role of microorganisms in biosorption of toxic metals and radionuclides, International Biodeterioration $\mathcal{E}$ Biodegradation, Vol. 35, No 1-3(August 2011),pp. 17-40, ISSN 0964-8305

Yalçin, S., Apak., R, Hizal J., Afsr, H. 2001. Recovery of copper(II) and chromium (III, VI) from electroplating-industry wastewater by ion exchange. Separation Science and Technology, Vol.36, No 10, pp. 2181-2196. ISSN 1520-5754

Yang, H.; Yan, R.; Chen, H.; Lee, D.H.; Zheng, C. (2007). Characteristics of hemicellulose, cellulose and lignin pyrolysis. Fuel. Vol. 86, pp. 1781-1788, ISSN 0016-2361

Yasemin, B. \& Zeki, T. (2007). Removal of heavy metals from aqueous solution by sawdust adsorption. Journal of Envirnnmental Sciences Vol. 19,No 2, pp. 160-166, ISSN: 10010742

Yazici, E.Y., Deveci, H., Alp I. \& Uslu, T. (2007). Generation of hydrogen peroxide and removal of cyanide from solutions using ultrasonic waves. Desalination Vol. 216, No 1-3, pp. 209-221, ISSN 0011-9164

Zafar, M.N., Nadeem, R.,Hanif, M.A. (2007). Biosorption of nickel from protonated rice bran, Journal of Hazardous Materials Vol.143, No 1-2, 478-485, ISSN 0304-3894

Zvinowanda, C., Okonkwo J. , Gurira, R. (2008). Improved derivatisation methods for the determination of free cyanide and cyanate in mine effluent. Journal of Hazardous Materials, Vol. 158, No 1, pp. 196-201,ISSN 0304-3894 


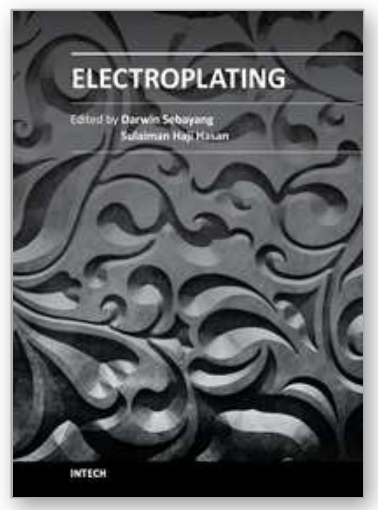

\author{
Electroplating \\ Edited by Prof. Darwin Sebayang
}

ISBN 978-953-51-0471-1

Hard cover, 166 pages

Publisher InTech

Published online 11, April, 2012

Published in print edition April, 2012

This book emphasizes on new applications of electroplating with consideration for environmental aspect and experimental design. Written by experienced expert from various countries, the authors come from academia and electroplating industrial players. Here, a very detailed explanation to the new application of the electroplating is followed by a solution of the environmental issue caused by the electroplating process and concluded by experimental design for optimization of electro deposition processes.

\title{
Coverage included:
}

- Preparation NiO catalyst on FeCrAl Subtrate Using Various Technique at Higher Oxidation Process

- Electrochemical properties of carbon- supported metal nanoparticle prepared by electroplating methods

- Fabrication of InGaN-Based Vertical Light Emitting Diodes Using Electroplating

- Integration Of Electrografted Layers for the Metallization of Deep Through Silicon Vias

- Biomass adsorbent for removal of toxic metal ions from electroplating industry wastewater

- Resistant fungal biodiversity of electroplating effluent and their metal tolerance index

- Experimental design and response surface analysis as available tools for statistical modeling and optimization of electrodeposition processes

\section{How to reference}

In order to correctly reference this scholarly work, feel free to copy and paste the following:

Ronaldo Ferreira do. Nascimento, Francisco Wagner de Sousa, Vicente Oliveira Sousa Neto, Pierre Basílio Almeida Fechine, Raimundo Nonato Pereira Teixeira, Paulo de Tarso C. Freire and Marcos Antônio AraujoSilva (2012). Biomass Adsorbent for Removal of Toxic Metal lons From Electroplating Industry Wastewater, Electroplating, Prof. Darwin Sebayang (Ed.), ISBN: 978-953-51-0471-1, InTech, Available from: http://www.intechopen.com/books/electroplating/biomass-adsorbent-for-removal-of-toxic-metal-ions-fromelectroplating-industry-wastewater

\section{INTECH}

open science | open minds

\section{InTech Europe}

University Campus STeP Ri

Slavka Krautzeka 83/A

51000 Rijeka, Croatia

\section{InTech China}

Unit 405, Office Block, Hotel Equatorial Shanghai

No.65, Yan An Road (West), Shanghai, 200040, China

中国上海市延安西路65号上海国际贵都大饭店办公楼 405 单元 
Phone: +385 (51) 770447

Fax: +385 (51) 686166

www.intechopen.com
Phone: +86-21-62489820

Fax: +86-21-62489821 
(C) 2012 The Author(s). Licensee IntechOpen. This is an open access article distributed under the terms of the Creative Commons Attribution 3.0 License, which permits unrestricted use, distribution, and reproduction in any medium, provided the original work is properly cited. 